\title{
Sosyal Bilgiler Öğretiminde Müze ve Tarihi Mekân Kullanımının 7. Sınıf Öğrencilerinin Sosyal Bilgiler Algılarına Etkisi: Bir Eylem Araştırması*
}

\section{The Impact of Utilizing Museums and Historic Places in Grade Seven Social Studies Teaching on Students' Perceptions of Social Studies: An Action Research}

\author{
Servet ÜZTEMUR ${ }^{* *}$
}

Erkan DíNÇ ${ }^{* * *}$

\author{
İsmail ACUN ${ }^{* * * * *}$
}

Received: 27 November 2017

Accepted: 14 January 2018

\begin{abstract}
The aim of this study is twofold. The first one is to practice the teaching activities designed to make use of museums and historical places within the context of grade seven social studies course. The second one is to reveal how and in which ways these activities influence students' perceptions of social studies. Designed as an action research, the current study employs 36 grade seven students (20 girls and 16 boys) attending to a public secondary school located in the district of Yunusemre attached to Manisa province as its study group. In order to carry out all phases of the proposed action research effectively, museums and historic places located in the immediate environment of the school were chosen. Manisa Museum, Muradiye Mosque, Museum of the History of Medicine, Historical Kula Houses, the Ancient City of Sardis, Sultaniye Complex, Keskinoğlu's Museum of Classical Vehicles, Manisa Grand Mosque, and Ravika Village Museum were included in the scope of the research. In total, 34 activities were prepared and implemented. The data obtained through observation and interviews was analyzed thematically, while the written records of students' works was subjected to content analysis. The results show that the implementation of research activities in museums and historical places provoked and changed students' perceptions of history. Their perceptions of history after the study include and favor local history and cultural elements.
\end{abstract}

Keywords: social studies, museum education, perception of social studies, action research.

ÖZ: Bu araştırmanın amacı, ilköğretim 7. sınıf sosyal bilgiler öğretimi bağlamında müzeler ve tarihi mekânlardan etkili yararlanmaya yönelik öğretim etkinlikleri tasarlayarak bu etkinlikleri uygulamak ve bu etkinliklerin öğrencilerin sosyal bilgiler algılarını nasıl ve ne yönde etkilediğini ortaya koymaktır. Nitel araştırma yöntemi temelinde eylem araştırması modeline göre desenlenen araştırma kapsamında Manisa ili Yunusemre ilçesindeki kamu ortaokulundaki 36 kişilik (20 kız, 16 erkek) bir sınıfla Manisa'nın müzeleri ve tarihi mekânları içerisinden seçilen dokuz ayrı mekâna (Manisa Müzesi, Muradiye Camisi, Tıp Tarihi Müzesi, tarihi Kula evleri, Sard Antik Kenti, Sultaniye Külliyesi, Keskinoğlu Klasik Araç Müzesi, Manisa Ulu Cami, Ravika Köyü Müzesi) yönelik müze öncesi okulda, müzede ve müze sonrası okulda olmak üzere toplamda 34 ayrı etkinlik geliştirilerek uygulanmıştır. Uygulamaların, öğrencilerin sosyal bilgiler algılarını nasıl ve ne yönde etkilediğini ortaya koymak amacıyla veri üretme aracı olarak gözlem, görüşme ve doküman analizi kullanılmıştır. Gözlem ve görüşmeler yoluyla elde edilen verilere içerik analizi; öğrenci ürünlerinden elde edilen verilere doküman analizi yapılmıştır. Araştırma sonucunda öğrencilerin sosyal bilgiler algılarının uygulamanın amacı doğrultusunda şekillendiği görülmüştür.

Anahtar kelimeler: sosyal bilgiler, müze eğitimi, sosyal bilgiler algısı, eylem araştırması.

\footnotetext{
* It was produced from a part of the first author's doctoral thesis.

** Corresponding Author: PhD, Ministry of Education, Manisa, Turkey, servetuztemur@gmail.com

*** Assoc. Prof. Dr., Usak University, Usak, Turkey, erkandinc@ gmail.com

***** Assoc. Prof. Dr., Eskisehir Osmangazi University, Eskişehir, Turkey, iacun@ogu.edu.tr
}

\section{Citation Information}

Üztemur, S., Dinç, E., \& Acun, İ. (2018). Sosyal bilgiler öğretiminde müze ve tarihi mekân kullanımının 7. sınıf öğrencilerinin sosyal bilgiler algılarına etkisi: Bir eylem araştırması. Kuramsal Eğitimbilim Dergisi [Journal of Theoretical Educational Science], 11(1), 135-168. 


\section{Giriş}

Öğrencilerin bilgiyi kendi zihinlerinde oluşturdukları, grup halinde işbirlikçi öğrenme ve problem çözme yöntemlerinin işe koşulduğu faaliyetler çağdaş eğitim anlayışının temel mantığını oluşturmaktadır. Öğrencilerin aktif olduğu bir öğrenme sürecinde kişisel yaşantılar önemli yer tutar. $\mathrm{Bu}$ durum eğitim-öğretim faaliyetlerinin okul dışına çıkması ve gerçek hayatla bütünleşerek iç içe olması demektir. Okul dışı eğitim, yapılandırılmış öğretim uygulamalarının okul dışındaki doğal çevre ve toplum gibi farklı mekânlarda çalışılmasını içeren çok yönlü bir süreçtir (Çengelci, 2013; Şimşek \& Kaymakçı, 2015). Öğrencilerin dünyayı anlamlandırabilmeleri ve gerçek öğrenme deneyimlerini tadabilmeleri için yaşadıkları doğal ve kültürel çevreyle, toplumla ve arkadaşlarıyla etkileşim kurmalarına yönelik imkânlar hazırlamak gerekmektedir. Buna rağmen günümüzde çocuklara okulda ve evde bu açıdan sağlanabilen imkânlar kısıtlıdır. Bununla birlikte öğrencinin çevresiyle kurduğu iletişim ve etkileşim doğrusal nitelikte olmayıp öğretmen, ders kitabı veya kitle iletişim araçlarının vasıtasıyla olmaktadır (San, 1990'dan akt. Adıgüzel \& Öztürk, 1999). Bunun sonucunda öğrenme daha çok bilişsel açıdan gerçekleşmekte, özellikle öğrenme sürecinde öğrencinin duygularının ve düş gücünün devreye girmesi engellenmektedir (Adıgüzel \& Öztürk, 1999). Tecrübelere dayanması, öğrencilerin yaparak-yaşayarak öğrenmesine imkân sağlaması, bütün duyuları kullanmayı zorunlu kılması, disiplinler arası konulara öncelik vermesi ve insanla doğal ortam arasındaki münasebetleri konu edinmesi okul dişı eğitimin özellikleri arasında sıralanabilir (Tokcan, 2015).

$\mathrm{Bu}$ araştırmada sosyal bilgiler dersi bağlamında okul dışı öğrenme ortamlarından müzeler ve tarihi mekânlar uygulama alanı olarak belirlenmiştir. Uluslararası Müzeler Konseyi (ICOM) tarafından 2007 yılında yenilenen ve halen geçerliliğini koruyan müze tanımı şu şekildedir: "Toplumun ve gelişiminin hizmetinde olan, halka açık, insana ve yaşadığı çevresine tanıklık etmiş somut ve soyut malzemelerin üzerinde araştırmalar yapan, toplayan, koruyan, bilgiyi paylaşan ve sonunda inceleme, eğitim ve zevk alma doğrultusunda sergileyen, kar amacı gütmeyen, sürekliliği olan bir kurum.” (International Council of Museums [ICOM], 2007). Yapılandırmacı yaklaşımın etkisiyle son yıllarda birincil kaynaklar ve nesnelerle etkileşimin sonucunda yaşantı temelli aktif öğrenmenin önemli görülmeye başlanması; eğitimde müzeler ve tarihi mekânların önemini artırmıştır (Hein, 1998; Hooper-Greenhill, 1999). Müzeler ve tarihi mekânlar, sosyal bilgiler ve tarih ders kitaplarının kültür ve medeniyetlere yönelik sunamayacağı değişik birincil kaynakları çocukların kullanımına sunabilir. Bunun yanı sıra müzeler ve tarihi mekânlarda öğrencide oluşturulabilecek ilgi ve merak sınıf ortamına götürülebilirse daha sonraki öğrenmeleri de güdüleyebilir. Müzeler ve tarihi mekânlar; öğrencilerin birinci el kaynaklardan bilgi toplayarak nesnelerin nasıl yorumlanması gerektiği konusunda fırsatlar sağlayabilir. Müzeler ve tarihi mekânlar etkili kullanıldığında öğrencilerde gözlem, düzenleme, akıl yürütme, çıkarım yapma, sınıflama, kestirme gibi becerileri gelişecektir (Ata, 2002).

Müze ve tarihi mekân temelli öğrenme, nesnelerin keşfedildiği ve bedensel bağlanmanın kışkırtıldığı dikkatle tasarımlanmış deneyimlere fiziksel bir dalma yoluyla gerçekleşir. Öğrenciler nesnelere dokunur, evleri ve bahçeleri keşfeder, merdivenlere tırmanır ve benzeri şeyleri rahatlıkla yaparlar. Bu dalış sırasında öğrenme kaynağ olarak duygularını ve bedenlerini kullanırlar. $\mathrm{Bu}$ nedenle okumak, dinlemek ve konuşmak gibi sözel süreçlerin gerçek bir öğrenme için yeterli olmadığı ve hissetme 
süreçlerinin bedensel eylem yoluyla işin içine girmesi gerektiği söylenebilir (HooperGreenhill, 2007). Müzeler ve tarihi mekânlar ile eğitimin esas amaçlarından biri de öğrencilerin düş gücünü uyarmak ve onların duyusal uyanıklığını geliştirmektir. Bu yüzden sınıfta başarmanın zor olduğu nitelikleri müzeler ve tarihi mekânların vereceği çok açıktır. Sergiledikleri eserler eleştirel düşünmeyi, yaratıcılığı ve merak duygusunu kamçılar. Geçmişin kültürlerine ve insanlarına daha duygusal bağlar yaratarak gerçeğe yakın olma şansını ve tarihle tanışma imkânını öğrencilere sunarak okul çocuklarının tarihe ilgisini çeker (Epik, 2004; Gartenhaus, 2000). Farmer ve Knight'a (1995'ten akt. Çulha-Özbaş, 2015a) göre tarihi mekânlar, çocuklar üzerinde tarihi canlandırma noktasında çok önemli bir yere sahiptir. Bu mekânlar geçmişte yaşamış insanların ne gibi şeyler yaptıklarına dair bilgi ve belgeyi bünyelerinde barındırır. Buralarda çocukların çevresi bütünüyle tarihle kuşatılmıştır. Müzeler aynı şekilde tarihin görsel hafızalarıdır. Bu nedenle çocukları bu türden tarih alanlarına çekmek, onları geçmişin atmosferini hissetmelerini sağlayarak tarihsel empati becerilerinin gelişmesinde onlara firsatlar sunar ve onların gözlem becerilerini geliştirir. Böylelikle öğrenciler tarihe yönelik olumlu tutum geliştirirler.

Sosyal bilgiler derslerindeki tarih konularının öğrenilmesinin daha anlamlı ve kalıcı hale getirilmesi için müzeler ve tarihi mekânların okul öğrenmelerinin tamamlayıcı bir parçası haline getirilmesi şarttır. Müzeler ve tarihi mekânlar, sosyal bilgiler ve tarih derslerini ders kitabı bağlamının sınırlılığından çıkarıp üç boyutlu somut olarak görülen o döneme ilişkin empati ve duyumsamaların yapılabildiği durum ve ortamlara dönüştürmektedir (Kabapınar, 2014). Klasik tarih konularının öğretiminde öğretmen genellikle öğrencilerinin daha önce hiç karşılaşmadığı ve büyük ihtimalle ileri zamanlarda da göremeyeceği konuları anlatmaktadır. Böyle bir öğretim şekli öğrenmeyi çok fazla soyutlaştırmaktadır. Müze ve tarihi mekânlarda ise öğrenciler bir araştırmacı edasıyla görerek, dokunarak ve koklayarak öğrenmekte ve bu süreçten zevk almaktadırlar. Klasik tarih öğretim yöntemleriyle işlenen bir derste zorlanan öğrenciler, müzelerde ve tarihi mekânlarda aktif katılım sağlayarak daha etkili öğrenmekte, tarihi canlandırmalara katılarak ve farklı meslekleri oynayarak gizli yeteneklerini ortaya koymaktadırlar (Seidel \& Hudson, 1999). Kelimelerin veremeyeceği heyecan ve güdülenmeyi müze ve tarihi mekânlar sağlamaktadır. Geçmişin somut mirası olan tarihi mekânlar öğrencilerde tarih bilincinin oluşmasında çok önemlidir (Gökkaya \& Yeşilbursa, 2009). Çağdaş eğitim anlayışlarının şekillendirdiği yeni sosyal bilgiler eğitiminde; siyasi tarih konularının kronolojik bir sırayla tek taraflı aktarımı ve ezberlenmesinden ziyade tarihsel empati, anlama ve düşünme becerilerinin geliştirilmesine yönelik çalışmalar önem kazanmıştır (Yılmaz \& Şeker, 2011). Müzeler ve tarihi mekânlar, sosyal bilgiler derslerindeki tarih konularının öğretimi için önemli bir kaynak oluşturur. Öğrenci tarih kitabındaki soyut olgulardan daha fazla şeylerin olduğunu müzelerde görür; çünkü sınıftakinin aksine müzeler ve tarihi mekânlardaki öğrenme gerçekçi ve görseldir. Bir olgu bilgisi vermekten ziyade öğrencinin merakını ve ilgisini çekmeyi amaçlar.

Sosyal bilgiler derslerindeki tarih konularının öğretiminde müzeler ve tarihi mekânların önemli kabul edilmesinin en temel nedeni tarihin vücuda bürünen somut kalıntılarını bünyelerinde barındırmalarıdır (Tezcan-Akmehmet, 2008). Müzeler ve tarihi mekânlar tarihin aradığı şeyleri, yani tarihin nesnelerini barındırır. Bu bakımdan bu yerler tarihin deposu ve hatta hazinesidir. Tarihi canlandırarak daha dokunulabilir 
hale getirirler. Bir başka ifadeyle müzeler ve tarihi mekânlarda tarihin ayak izleri görülür (Epik, 2004). Müzeler ve tarihi mekânlarda öğretim, öğrencileri küçük tarihçilere dönüştürür; çünkü öğrenciler nesneleri, gerçek maddi kaynakları, tarihi fotoğraf ve haritaları ve farklı dokümanları kullanarak yaşadıkları toplumun tarihini araştırırlar (Yeşilbursa, 2008). Öğrenciler geçmişe yönelik bilgiler toplayarak detayları öğrenirler ve bu sayede ulaştıkları kaynakları kanıta çevirme becerisini kazanabilirler. Kanıt temelli öğrenme süreci sonunda öğrenciler yeni şeyler keşfetmenin hazzını yaşarken aynı zamanda kendi sonuçlarını elde edip yorumlama şansını bulurlar (Doğan, 2007; Husbands, 1992). Müze ve tarihi mekân ziyaretlerinin en iyi yanı; öğrencilerin tarihi kaynaklara doğrudan ulaşarak akademik tarihçilerin kaynakları kanıta dönüştürmede yaptıkları gibi kendi kararlarını vermelerini sağlamasıdır. Bu süreçte öğrenciler tarihin birincil belgeleriyle yüzleşerek tarih yazanların gerçek cümlelerine ulaşırlar (Horton, 2000). Birinci elden kaynaklarla çalışmak öğrencilerin içsel motivasyonunu, öz saygılarını ve derse yönelik tutumlarını olumlu yönde etkilemektedir (Doğan \& Dinç, 2007). Müze ve tarihi mekânlarda gerçek nesnelere dayalı öğretim etkinlikleri sayesinde öğrenciler, geçmiş yaşantıları öğrenerek günümüzle mukayese eder. Aynı zamanda öğrendikleri bilgileri gelecekle bağlantılar kurmak için kullanır. Bu durumun bir sonucu olarak öğrencilerde tarihi bilinç gelişmekle birlikte aynı zamanda öğrencilerin tarihin güncel hayattaki etkisini net bir şekilde görmeleri sağlanır (TezcanAkmehmet, 2008). Amerikan Sosyal Bilgiler Eğitimi Komitesi, öğretmenlere kendi toplumlarıyla birlikte çalışma imkânı sağlama ve öğrencilerin sorumluluk alıp sosyalleşmelerini isteklendirme gibi özelliklerinden dolayı tarihi mekânların eğitim ortamında kullanılmasını önermektedir (Çulha-Özbaş, 2015b). Müze ve tarihi mekânlarda gerçekleştirilen etkinlikler tarihi kavramların daha kolay öğrenilmesini sağlar. Nesneler ve gerçek kalıntılarla çalışıp deneyim kazanma sonucunda tarihi kavram ve konuların somutlaştırılması ve daha iyi anlaşılması sağlanır. Özellikle somut işlemler dönemindeki ilköğretim öğrencilerine somut nesnelerle çalışma firsatı verilmesi, algılar ve kavramlar arasındaki bütünleşmeyi sağlayabilir. (Kyvig ve diğerleri, 2000'den akt. Tezcan-Akmehmet, 2008).

Günümüzde öğrenciler ve öğretmenler müzelerin en önemli hedef kitleleri haline gelmiştir. Gelişmiş ülkelerde bürokratik engeller kaldırılarak okul ve müze arasındaki ilişkiler bir sisteme oturtulmuştur. Bu yenilikler neticesinde müzeler de okullara yönelik eğitim faaliyetlerine daha fazla önem vermeye, sergilerini öğretim programlarıyla uyumlu bir şekilde düzenlemeye ve doğrudan bu programlarla ilişkili etkinlikler hazırlamaya başlamışlardır (Tezcan-Akmehmet, 2005). Türkiye şartları düşünüldügünde müzelerin eğitim işlevini tam anlamıyla yerine getiremedikleri görülmektedir. Türkiye'de müzelere kültürel mirasın korunmasını geliştirme gibi bir amaç yüklenmesine rağmen, daha ilk çağlardan itibaren bu yerlerin ilham perilerinin evi olarak görülmesi ve yenilikçi fikirlerin geliştirildiği yerler olarak kabul edilmesi yaklaşımı ne yazık ki Türkiye'de pek yaygınlaşamamıştır (Ata, 2009). Bünyesinde müze eğitimcisi bulunduran ve aynı zamanda çocuklara, yetişkinlere ve okullara eğitim hizmeti veren müzeler Türkiye'deki toplam müze sayısına oranla çok az durumdadır. $\mathrm{Bu}$ durumun doğal bir sonucu olarak Türkiye'de müzeler; kendi kabuğuna çekilmiş, toplumdan uzak ve soğuk duvarlarla örülmüş binalar olarak algılanmaktadır.

Türkiye'de müzeler bir eğitim aracı olarak kullanılamamakta, okul-müze arasında işbirliği istenilen şekilde yapılamamaktadır. Okulların müzeler ve tarihi 
mekânlarla ile münasebetleri genellikle toplu bir okul veya sınıf gezisi şeklindedir. Bu gezilerde öğrenciler çoğu zaman tek sıra halinde sessiz bir şekilde camın arkasında yer alan nesnelere bakıp geçmekte ve öğrenciler ile tarihi nesneler arasında herhangi bir etkileşim yaşanmamaktadır. Doğal olarak böyle bir müze gezisinin çocukta aktif katılımı ve yaratıcılığı geliştirdiği söylenemez. Müze ve tarihi mekânlarda öğrenme faaliyeti nesnenin başında çoğu zaman müze rehberinin veya öğretmenin açıklamalarından öteye geçememektedir. Bu açıklamaları pasif bir şekilde dinleyen öğrenciler zamanla sıkılmakta ve bunun sonucunda kalıcı öğrenmeler oluşmamaktadır. Çağdaş müze eğitiminde çocukların aktif katılım sağladığı nesne merkezli eğitim yöntemi kullanılmaktadır. Dört bir yanı müze ve tarihi mekânlarla donatılmış ülkemizde, eğitimde bu denli önemli olanaklara sahip olan müzelerden aktif bir biçimde yararlanılamadığı ortadadır. Müzelerin esas görevi olan eğitimin etkili olabilmesi için, en kısa zamanda öğrencilere yönelik etkinliklerin hazırlanıp işe koyulması gerekmektedir. Hazırlanan etkinliklerin etkili bir biçimde uygulanabilmesi için de, bu konuda eğitim alarak kendini geliştirmiş ve uygulama yapabilecek öğretmenlerin yetişmesi lazımdır (Şar \& Sağkol, 2013). Öğretmenlerin müze ve tarihi mekânlarda nesne temelli etkinliklerden pek fazla haberdar olmadığ 1 yapılan çalışmalarda ortaya konulmuştur (Aktekin, 2008; Ar1, 2010; Ata, 2002; Avc1-Akçalı, 2015; Avc1 \& Öner, 2015; Demir, 2015; De Witt \& Storksdieck, 2008; K1sa, 2012; Öner, 2015). Sosyal bilgiler dersi bağlamında müzeler ve tarihi mekânlarımızın birer eğitim ortamına dönüştürülerek öğrencilerin bu yerlerde yaparak-yaşayarak öğrenmeleri ve yaratıcı düşünme becerilerinin geliştirilmesi için müze eğitim etkinliklerinin tasarlanması ihtiyacı ortaya çıkmıştır.

$\mathrm{Bu}$ araştırmanın amacı, ilköğretim 7. sınıf sosyal bilgiler öğretimi bağlamında müzeler ve tarihi mekânlardan etkili yararlanmaya yönelik öğretim etkinlikleri tasarlayarak bu etkinlikleri uygulamak ve bu etkinliklerin öğrencilerin sosyal bilgiler algılarını nasıl ve ne yönde etkilediğini ortaya koymaktır. Araştırmanın amacı doğrultusunda aşağıdaki soruya cevap aranmıştır:

"Geliştirilen etkinlikler ve uygulamalar, öğrencilerin sosyal bilgiler dersine yönelik alg1 ve görüşlerini olumlu yönde değiştirmekte midir?"

\section{Yöntem}

\section{Araştırmanın Modeli}

Araştırma nitel araştırma yöntemlerinden eylem araştırması desenine göre modellenmiştir. Kurt Lewin'in 1900'lü yılların ortalarında yaptığı çalışmalar (Cohen, Manion, \& Morrison, 2007; Glesne, 2014) sonucu ortaya çıkan eylem araştırmasındaki temel amaç; öğrenme faaliyetlerinin niteliğinin artırılmasıyla birlikte okul şartlarının iyileştirilmesidir (Altrichter, Posch, \& Somekh, 2000; Hensen, 1996).

Müze ve tarihi mekânlara yönelik etkinlikler geliştirip uygulama sürecinde araştırmacıların sürecin her aşamasına hâkim olması ve uygulama esnasında meydana gelen aksaklıkların çözümlenmesi amacıyla araştırma modeli olarak eylem araştırması seçilmiştir. Eylem araştırmasının mevcut araştırmanın yapısına en uygun araştırma modeli olması ve araştırmacının kendi okulunda var olan bir sorunu çözmeye yönelik bir eylem planı geliştirmesi nedeniyle eylem araştırması (öğretmen araştırması) modeli seçilmiştir. 


\section{Çalışma Grubu}

Araştırmanın çalışma grubunu, 2016-2017 öğretim yılında birinci yazarın sosyal bilgiler öğretmeni olarak görev yaptığı Manisa ili merkez Yunusemre ilçesindeki bir kamu ortaokulunun 36 öğrenciden (20 kız, 16 erkek) oluşan 7. sınıf öğrencileri oluşturmaktadır.

\section{Eylem Araştırması Süreci}

Araştırmacılar ilk aşamada, sosyal bilgiler öğretiminde müzeler ve tarihi mekânların etkin bir şekilde kullanılamadığını ve Türkiye alanyazınında müzeler ve tarihi mekânların etkin kullanımına yönelik yapılan örnek uygulamaların azlığını fark edip bu konuda çalışma yapılması ihtiyacı hissetmişlerdir.

İkinci aşamada araştırma kapsamına alınacak müzeler ve tarihi mekânların belirlenmesinde sosyal bilgiler öğretimine yönelik etkinliklerin yapılabilir olması, öğrencilerin seviyesine uygun olması, okula yakın ve ulaşımının kolay olması ve sosyal bilgilere özgü becerileri kazandırabilecek özellikte olmasına dikkat edilmiştir. $\mathrm{Bu}$ durumun neticesinde Türkiye'nin batısında yer alan Manisa ili sınırları içerisinde yer alan Manisa Müzesi, Sultaniye Külliyesi, Tıp Tarihi Müzesi, Muradiye Külliyesi, Manisa Ulu Cami, Klasik Araç Müzesi, Sard Antik Kenti, Tarihi Kula Evleri ve Ravika Köyü Müzesi araştırma kapsamına alınmıştır.

Üçüncü aşamada yukarıda belirtilen müze ve tarihi mekânları kapsayan müze öncesi okulda, müzede ve müze sonrası okulda boyutlarını içeren toplamda 34 etkinlik geliştirilmiştir. Toplam 34 etkinlikten 21'i çalışma yaprağı, 6'sı okul dışında grupça araştırma yapıp sınıfta sunum yapma, 4'ü müze/tarihi mekânda canlandırma yapma türündedir. Müze ve tarihi mekân öğrenmelerinin duyuşsal alana da hitap etmesi nedeniyle yaratıcı drama türünde üç adet etkinlik uygulanmıştır. Yaratıcı drama etkinliklerinin seçiminde araştırma kapsamına alınan mekânların fiziksel koşulları göz önüne alınmış ve bunun sonucunda Manisa Müzesi, Tıp Tarihi Müzesi ve Sardes Antik Kenti'nde yaratıcı drama etkinlikleri uygulanmasına karar verilmiştir. Yaratıcı drama etkinliklerinde sınıf 18 'er kişilik iki gruba ayrılmıştır. Etkinliklerin öğrencilerin seviyelerine uygun olmasına dikkat edilmiştir. Araştırmacılar, etkinlikleri geliştirirken ilgili alanyazında içeriğinde müze ve/veya tarihi mekânlara yönelik uygulama yapılan lisansüstü tezleri göz önüne almıştır (Akça-Berk, 2012; Avcı-Akçalı, 2013; Çerkez, 2011; Çulha, 2006; Filiz, 2010; Yorulmaz, 2016).

Etkinlik yazımı esnasında etkinliklerin dil, kavram, açıklık, anlaşılırlık, konu alanına uygunluk, sosyal bilgilere özgü becerilere uygunluk açısından 7. sınıf öğrencilerinin seviyesine uygunluğu konusunda; üç sosyal bilgiler eğitimcisi ve bir tarih eğitimcisinden uzman görüşü alınmıştır. Etkinliklerde geçen kavramların öğrencilerin seviyesine uygunluğu, uygulamalardan önceki derslerde bizzat sınanmıştır. Okulda görev yapan diğer sosyal bilgiler öğretmenlerinin de görüşü alınarak gerekli düzeltmeler yapılmıştır.

Uygulamalar 2017 y1lı Mart ayının ikinci yarısı ile Mayıs ayının ilk yarıs1 arasında gerçekleştirilmiştir. Uygulamalara başlamadan önce sınıftaki öğrencilerinin sosyal bilgiler dersine yönelik algı ve tutumlarını ortaya koymak, müzelere ve tarihi mekânlara ilişkin bilişsel, duyuşsal ve sosyal özelliklerini anlamak amaciyla odak grup görüşmeleri yapılmıştır. Araştırmacılar odak grup görüşmeleri öncesinde sınıfı beş 
gruba ayırmıştır. Grupları belirlerken heterojen bir yapıda olmaları için cinsiyet dengesini gözetmiştir. Ön odak grup görüşmeleriyle öğrencilerin eylem planı öncesinde mevcut alg1, tutum, görüş ve farkındalık düzeyleri belirlenmeye çalış1lmıştır. Araştırmacılar uygulamalara başlamadan önce araştırmanın genel mantığını öğrencilerle paylaşarak onları süreç hakkında bilgilendirmiştir. Bunun yanı sıra veli toplantısı yapılarak veliler bilgilendirilmiştir. Veliler, araştırmanın geneli boyunca destek olarak araştırmacıya herhangi bir sıkıntı yaşatmamıştır. Odak grup görüşmelerinden sonra uygulamalar gerçekleştirilmiştir. Müzeler ve tarihi mekânlarda etkinlikler yapmadan önce öğrencileri hem konuya isındırmak hem de Manisa'nın tarihi ve kültürel değerlerine yönelik farkındalık seviyelerini artırmak amacıyla okulda müze öncesi etkinlikler yapılmıştır. Süreç bu şekilde devam ederek araştırma kapsamındaki müzeler ve tarihi mekânlarda uygulamalar yapılmıştır. Müze ve tarihi mekân ziyaretleri sonrasında müze sonrası etkinlikler okulda yapılmıştır. Uygulama sürecinin her aşamasında veri toplama işlemi yapılmıştır. Araştırmanın genel bir değerlendirmesini yapmak amaciyla daha önce oluşturulan gruplarla tekrardan odak grup görüşmeleri yapılmıştır. Bu şekilde öğrencilerin araştırma süreci boyunca öğrendikleri, hissettikleri, düşündükleri vb. şeyleri kendi ağızlarından aktarmaları sağlanmıştır.

\section{Veri Toplama Araçları}

Müze ve tarihi mekânlardaki öğrenme süreci, daha çok yaşantıya dayalı ve duyuşsal alanı da hedeflediği için standartlaştırılmış nicel ölçme araçlarından ziyade araştırmanın bütüncül yapısına uygun olduğu varsayılan nitel veri toplama araçları kullanılmıştır. Nitel veri toplama işlemi; gözlem (araştırmacı saha notları, araştırmacı günlüğü, video kayıtları), görüşme (odak grup görüşmeleri, bireysel görüşmeler) ve yazılı kayıtlar (öğrenci günlüğü, öğrenci ürün dosyası, uygulanan etkinlikler, veli görüş formu) aracılığıyla sağlanmıştır.

Yarı yapılandırılmış görüşme formları aracılığıyla öğrencilerin süreç başında ve süreç sonunda görüş, alg1 ve farkındalıkları ortaya konulmaya çalışılmıştır. Yarı yapılandırılmış görüşme formları hazırlanırken üç sosyal bilgiler eğitimcisinden uzman görüşü alınmıştır. Uygulamalara başlamadan önceki odak grup görüşmeleri yaklaşık otuz dakika sürerken; uygulama sonundakiler ise ortalama bir saati bulmuştur. Araştırmacılar uygulamaların tamamında öğrencileri gözlemleyerek gerekli notlar almıştır. Uygulamaların bazı bölümleri videoya kaydedilmiştir. Ayrıca her uygulamadan sonra öğrenciler; o gün öğrendikleri şeyleri, duygu-düşünce ve hissettiklerini anlatan günlük tutmuşlardır. Öğrencilere günlük tutma yönergesi verilerek günlüklerde nelerden bahsetmeleri gerektiği hakkında öğrencilere yol gösterilmiştir. Geliştirilen etkinlikler, araştırmanın amacı doğrultusunda öğrencilerin sosyal bilgiler algılarını olumlu yönde değiştirmesinin yanı sıra veri toplama aracı olarak da işlev görmüştür.

\section{Verilerin Çözümlenmesi}

Gözlem, görüşme ve yazılı kayıtlardan elde edilen verilere içerik analizi uygulanmıştır. İçerik analizi, bulguların düzenlenerek sınıflandırılması ve karşılaştırılarak kuramsal sonuçlara ulaşılması aşamalarını içeren bir nitel veri analizi yöntemidir (Cohen ve diğerleri, 2007). İçerik analizi yapılırken sürekli karşılaştırma analizi yönteminden faydalanılmıştır. Sürekli karşılaştırma analizi sürecinin aşamaları Diyagram 1'de gösterilmiştir. 
Diyagram 1. Sürekli Karşılaştırma Analizi Aşamaları

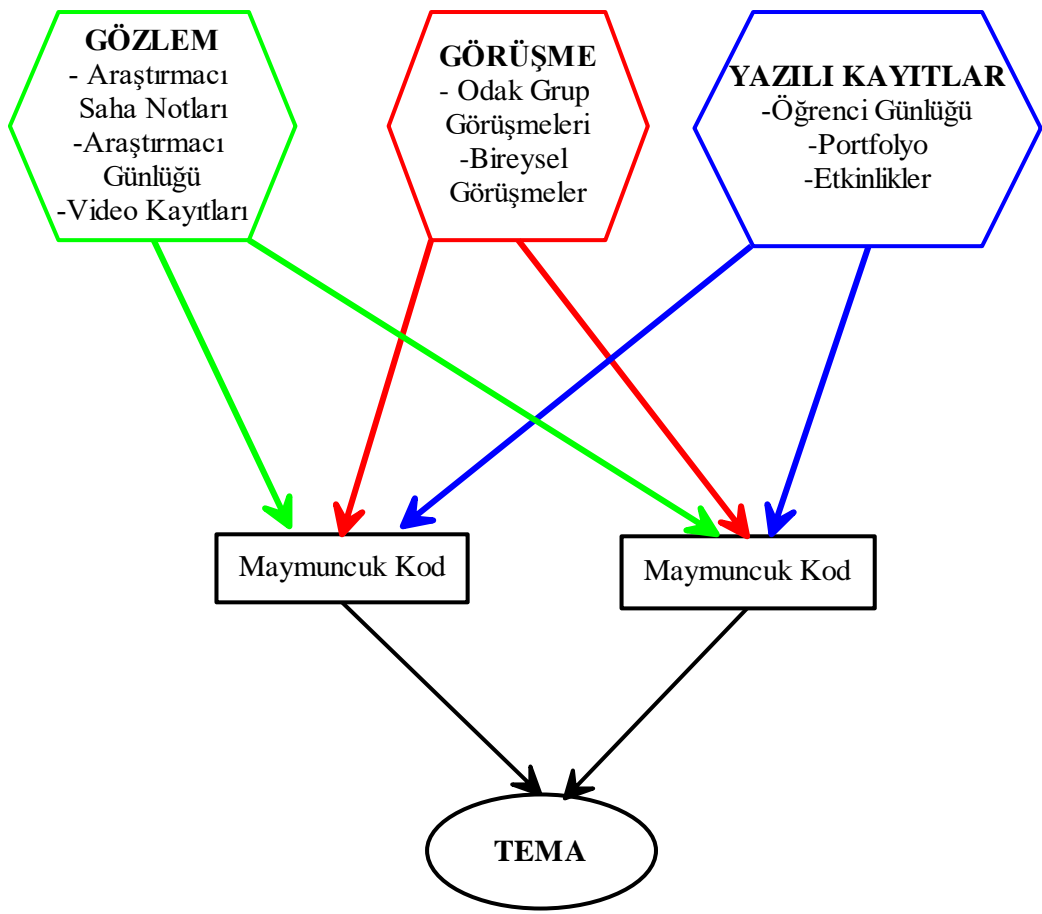

NİTEL VERİLER

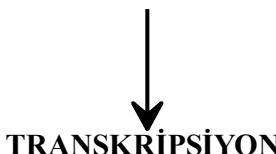
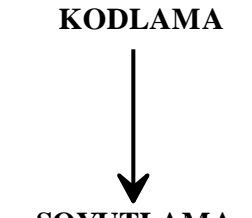

TEMALARA ULAȘMA

Nitel veriler kelime işlemci programında kelime birimlerine ayrılarak analize hazır hale getirilmiştir. Veriler defalarca okunup karşılaştırılarak kodlamalar yapılmıştır. Karşılaştırma, soyut kavramları belirlemede ve kodlamada önem taşır. Kodlamanın ilk aşamasında, verilerdeki farklı görüngüleri karşılaştırarak görgül verilerden daha soyut kavramlara ulaşılır. Dolayısıyla soyutluk düzeyini arttırmayı ve kavramları geliştirmek için oldukça önemli olan "yukarı taşımayı" sağlayan şey karşılaştırmadır (Punch, 2005: 198). Kodlama yapılırken ilgili fenomeni en iyi şekilde karşılayacak her bir veri setine özel kodlar ve üç grup veri setini de (gözlem, görüşme ve yazılı kaynaklar) analiz etmeye uygun maymuncuk kodlar kullanılmıştır. Her bir veri seti için kavramsallaştırmayı sağlayacak münferit kodlar ham verinin temaya evrilmesinde genel çerçeve oluşturmaya yardımcı olurken, maymuncuk kodlar sürekli karşılaştırma analizi sürecinde farklı türden verilerin bir arada olması nedeniyle her bir veri setinin ortak yönlerini içeren ve aynı grupta yer alıp anlamlı bir bütün oluşturanlarını sağlamıştır. Maymuncuk kodlar sayesinde birbirinden ayrı gibi görünen ama aslında aynı sürecin farkı türden yansımaları olan çeşitli verilerin benzer ve anlamlı yönleri tek bir çatıda birleştirilerek soyutlama işleminin ilk aşaması gerçekleştirilir.

Maymuncuk kodlar, ham verilerin soyutlama aşamasına doğru "yukarı çıkması" sürecinde merkezi bir rol üstlenirler. Soyutlama aşamasında ise maymuncuk kodlar arasında karşılaştırma işlemi yapılarak benzer özelliğe sahip ve anlamca birbirine yakın olanlar aynı kategoride (tema) değerlendirilmiştir. Alıntılarda sürekli karşılaştırma yöntemine uygun olarak nitel veriler bir arada sunulmuştur. Uygulamalardan önce odak grup görüşmeleri için sınıf beş gruba ayrılmıştır. Grup isimlerini öğrenciler kendileri belirlemiştir. Buna göre Ayyıldızlar (AY), Genç Tayfalar (GENÇ), Süper Gezginler (SÜP), Görgülüler (GÖR) ve Gezgin Tayfalar (GEZ) grupları oluşmuştur. Öğrenciler bulundukları grup adı, gruptaki sırası ve cinsiyetlerine göre kodlanmıştır. Örneğin "AY1K" kodu Ayyıldız grubundaki 1. sırada yer alan ve cinsiyeti kız olan öğrenciyi betimlemektedir. 


\section{Bulgular}

Öğrencilerin uygulamalara başlamadan önceki sosyal bilgiler algılarını ortaya koymak amacıyla ön odak grup görüşmelerinde "Sosyal bilgiler deyince aklınıza neler geliyor? Sosyal bilgiler size neyi çağrıştırıyor?” sorusu yöneltilmiştir. Öğrencilerin uygulamalar öncesindeki sosyal bilgiler algısı, ön odak grup görüşmelerindeki verilerden ortaya çıkarılarak Diyagram 2'de verilmiştir.

Diyagram 2. Öğrencilerin Uygulamalar Öncesi Sosyal Bilgiler Algıları

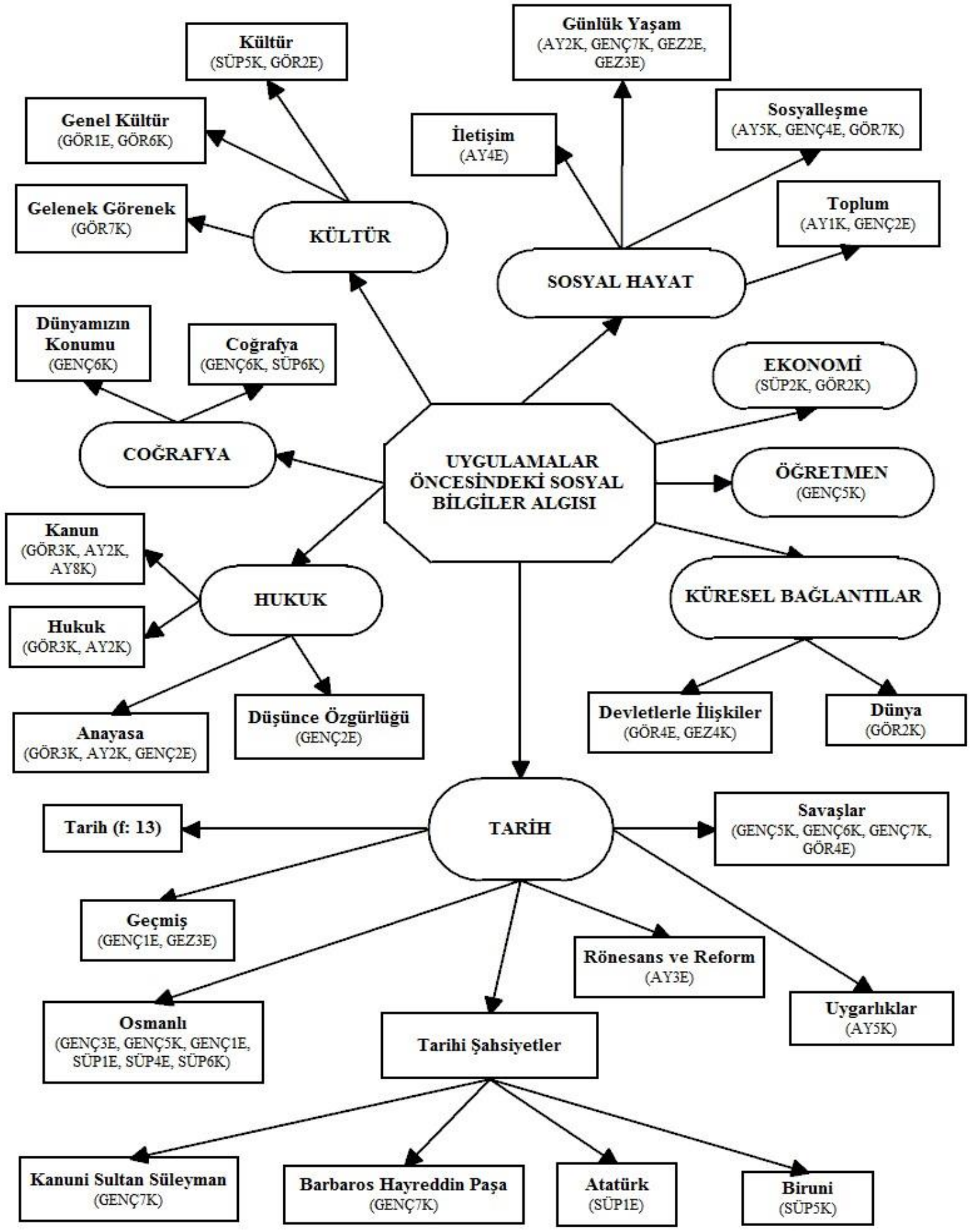

Diyagram 2 incelendiğinde öğrencilerin sosyal bilgiler algıları; tarih, sosyal hayat, hukuk, kültür, küresel bağlantılar, ekonomi ve ögretmen kategorileri altında toplanmıştır. 
Tarih ana kategorisi altında; tarih, Osmanlı devleti, savaşlar, tarihi şahsiyetler, geçmiş, uygarlıklar, Rönesans ve Reform alt kategorileri yer almaktadır. Öğrencilerin büyük bir bölümünün sosyal bilgiler dersini tarih disipliniyle özdeşleştirdiği yorumu yapılabilir. Sosyal hayat kategorisinde öğrenciler günlük yaşamdaki sosyalleşmeye, içinde yaşanılan topluma ve 7. sınıf sosyal bilgiler dersinin ilk ünitesi olan iletişim konusuna vurgu yapmışlardır. Hukuk kategorisinde öğrenciler anayasa, kanun, hukuk ve düşünce özgürlüğü konularına değinmişlerdir. Öğrenciler kültür kategorisinde sosyal bilgileri kültür, gelenek ve görenekler ve genel kültür ile özdeş tutmuşlardır. Küresel bağlantılar kategorisinde öğrenciler Türkiye'nin diğer dünya devletleriyle olan ilişkilerine değinmişlerdir. Sosyal bilgileri coğrafya disipliniyle özdeşleştiren öğrenciler akıllarına sosyal bilgiler deyince dünyamızın konumu ve coğrafya geldiğini beyan etmişlerdir. Bir öğrenci ise sosyal bilgiler ile dersin öğretmenini özdeşleştirmiştir.

Öğrencilerin sosyal bilgiler algılarına bakıldığında daha çok genel kavramlara değindikleri ve sığ açıklamalar yaptıkları görülmüştür. Örneğin sosyal bilgileri ekonomi disipliniyle özdeşleştiren öğrenciler ekonomiyle ilgili herhangi bir açılama yapamamışlardır. Tarih kategorisi içerisinde sosyal bilgiler deyince aklıma tarih geliyor diyen öğrencilere ne türden tarih sorusu sorulduğunda aklıma tarih konuları geliyor diyerek çok açıklayıcı cevaplar veremedikleri görülmüştür.

Uygulamalarda müze öncesi etkinlikler ile Manisa'nın 1313 yılında Saruhanlılar tarafından fethedilmesiyle başlayan kentin Türkleşme süreci, Osmanlı devleti zamanında şehzadelerin yetiştiği sancak beyliği olması ve nüfusunun artarak genişlemesiyle birlikte tarihi ve kültürel eserlerle Manisa'nın geçmişten günümüze gelişimi ve değişimi ele alınmıştır. İki ay süren uygulamalarda sosyal bilgiler dersini oluşturan sosyal bilim disiplinleri içerisinde yer alan tarih disiplinine yönelik yoğun bir bilgilenme, bilinç ve farkındalık artıran etkinlik programı uygulanarak öğrencilerin yaşadıkları yerin tarihi ve kültürel özelliklerini daha yakından tanıyarak içselleştirmeleri sağlanmaya çalışılmıştır. Uygulamalar sonundaki odak grup görüşmelerinde öğrencilerin sosyal bilgiler algıları Diyagram 3 'te gösterilmiştir.

Diyagram 3 incelendiğinde, Diyagram 2'de yer alan hukuk, coğrafya, küresel bağlantılar, ekonomi kategorilerinin yer almadığ 1 görülmektedir. Uygulama sonrasında öğrencilerin sosyal bilgiler algılarında daha önce var olmayan müze ve tarihi mekân uygulamaları kategorisi ortaya çıkmıştır. $\mathrm{Bu}$ durum, öğrencilerin sosyal bilgiler algılarının uygulamalar neticesinde istenilen yönde değiştiği şeklinde yorumlanabilir. Bunun yanı sıra tarih kategorisinin tekrarlanma sıklığının gözle görülür bir şekilde arttığ1 gözlenmektedir. Tarih kategorisinde uygulama öncesindeki tarihi şahsiyetler, Rönesans ve Reform, geçmiş, uygarlıklar alt kategorilerinin uygulama sonrasında yer almadığı görülmektedir. Bunların yerini tarihi eşyalar, tarihi yapıtlar, tarihsel empati kategorilerinin aldığı görülmektedir. Sosyal hayat kategorisinin tekrarlanma sıklığı artarken kültür kategorisinin ise azalmıştır.

Müze ve tarihi mekân uygulamaları ana kategorisi altında sırasıyla eğlence, müzeler, camiler, etkinlikler, müze nesneleri, medreseler ve külliyeler, gezmek ve görmek, tarihi mekânlar ve mezarlıklar alt kategorileri yer almaktadır. Eğlence kategorisinde öğrenciler uygulamalarla eğlenerek öğrendiklerini ve sosyal bilgiler dersinin sıkıcılıktan kurtulduğunu dile getirmişlerdir. Bu duruma örnek olarak AY6K kodlu öğrencinin görüşleri şu şekildedir: 
"Eskiden sosyal bilgiler deyince aklıma sıkıcılık ve tarih geliyordu; ama bu etkinliklere başladıktan sonra sosyal bilgiler deyince aklıma eğlence geliyor." (AY6K).

Diyagram 3. Öğrencilerin Uygulamalar Sonrası Sosyal Bilgiler Algıları

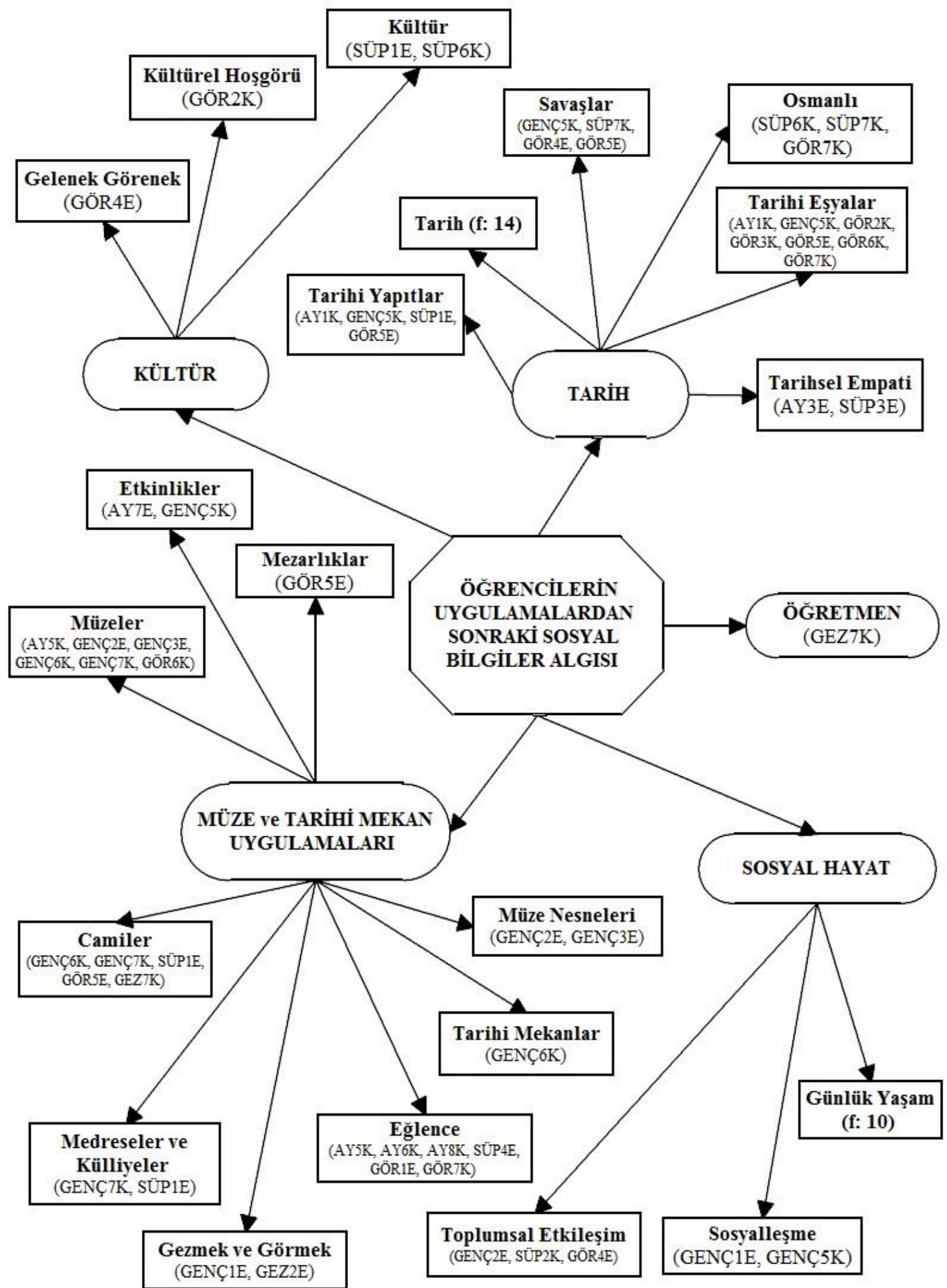

Yukarıdaki açıklamalardan öğrencilerin sosyal bilgiler dersine yönelik algılarının olumlu yönde değiştiği ve sosyal bilgileri eğlenceli bir ders olarak yorumladıkları sonucu çıkarılabilir. Öğrenciler uygulamaların etkisiyle sosyal bilgiler 
deyince akıllarına müzeler ve müze nesneleri geldiğini belirtmişlerdir. Bu duruma örnek olması açısından aşağıda doğrudan alıntılara yer verilmiştir: (GÖR6K).

"Manisa Müzesi aklıma geliyor. Osmanlıdaki eşyalar aklıma geliyor."

“Müzeler ve müzelerin içindeki yapılar aklıma geliyor." (GENÇ3E).

Öğrencilerin bir kısmı sosyal bilgiler deyince akıllarına camilerin geldiğini beyan etmişlerdir. $\mathrm{Bu}$ durumun ortaya çıkmasında üç ayrı tarihi camide yapılan etkinliklerin rolü büyüktür. Tarih ana kategorisi içerisinde sırasıyla tarih, tarihi eşyalar, tarihi yapitlar, savaşlar, Osmanl, tarihsel empati kategorileri yer almaktadır. Öğrenciler uygulamalarla birlikte tarihe olan ilgilerinin arttığını, tarihi daha iyi anladıklarını ve tarihte yaşanmış olayların nasıl yapıldığını merak ettiklerini beyan etmişlerdir. Bu konudaki örnek alıntı aşağıdaki verilmiştir:

"Önceden tarihi seviyordum; ama bu kadar sevmiyordum. Tarihe artı geziler sayesinde daha çok ilgim oldu. Eskiden aklıma bir şey gelse tarihi araştırmazdım; ama bu geziler sonrasında eve gidip Osmanlıda olan şeyleri araştırıyorum artık. Bu geziler sonrasında ĕglenceli geçmeye başladı. Sosyal bilgiler dediğimde eğlenceli tarih geliyor aklıma." (GÖR1E).

Öğrencilerin bir kısmı ise sosyal bilgiler deyince akıllarına uygulamalar esnasında müzeler ve tarihi mekânlarda gördükleri tarihi eşyalar geldiğini söylemişlerdir. $\mathrm{Bu}$ duruma örnek olarak GÖR7K kodlu öğrencinin görüşleri şu şekildedir:

"Bu gezilerden sonra aklıma eski dönem tarihler geliyor. Osmanlı devletindeki eserler aklıma geliyor. Osmanlıların tarihi geliyor. Aklıma işlemeler ve süslemeler geliyor." (GÖR7K).

Sosyal hayat kategorisinde öğrenciler sosyal bilgileri günlük hayat ve sosyalleşme ile özdeşleştirmiştir. Bu kategoriye ait örnek alıntı aşağıdaki gibidir:

"Yaşam, yaşam stili, her şeyle alakalıdır. Bu etkinliklerden sonra aklıma hayat geliyor. Önceden benim için hiçbir şey ifade etmiyordu. Sevmiyordum bile ama şimdi seviyorum yani değişiyor her şey. Dersi daha iyi işlediğimiz için, diğer derslerden farklı olduğu için." (AY2K).

Yukarıdaki alıntılardan öğrencilerin sosyal bilgileri hayatın her alanında var olan ve her şeyle ilişkili bir ders olarak algıladıkları yorumu yapılabilir. Uygulamaların öğrencilerin sosyal bilgiler dersine bakış açılarını değiştirip değiştirmediğini öğrenmek amaciyla uygulamalardan önce ve sonra öğrencilere "Çok sevdiğiniz dersleri sıraladığınızda sosyal bilgiler dersi kaçıncı sırada yer alır?” sorusu yöneltilmiştir. Öğrencilerin uygulama öncesi ve sonrası sosyal bilgiler dersi sıralamasında yaşanan değişim Tablo 1'de gösterilmiştir.

Ön odak grup görüşmelerinde çok sevilen dersler sıralamasında sosyal bilgiler dersini; öğrencilerin \%52.77'si 3. sirada, \%22.22'si 2. sirada, \%16.66's1 4. sirada, $\% 5.55$ 'i 1. sırada ve $\% 2.77$ 'si 5. sırada seçmiştir. Öğrencilerin ön odak grup görüşmelerinde sosyal bilgiler dersini çok sevilen dersler listesinde sıralamadaki yerini belirleme gerekçeleri Diyagram 4'te gösterilmiştir. 
Tablo 1

Öğrencilerin Sosyal Bilgiler Dersi Stralamalarında Yaşanan Değişim

\begin{tabular}{lllll}
\hline \multirow{2}{*}{ Siralama } & \multicolumn{2}{l}{ Ön Odak Grup Görüssmesi } & \multicolumn{2}{l}{ Son Odak Grup Görüsmesi } \\
& $n$ & $\%$ & $n$ & $\%$ \\
1. & 2 & 5.55 & 16 & 44.44 \\
2. & 8 & 22.22 & 20 & 55.56 \\
3. & 19 & 52.77 & - & - \\
4. & 6 & 16.66 & - & - \\
5. & 1 & 2.77 & - & - \\
\hline
\end{tabular}

Diyagram 4. Ön Odak Grup Görüşmesinde Sosyal Bilgiler Dersinin Sevilen Dersler Sıralamasındaki Yerinin Gerekçeleri

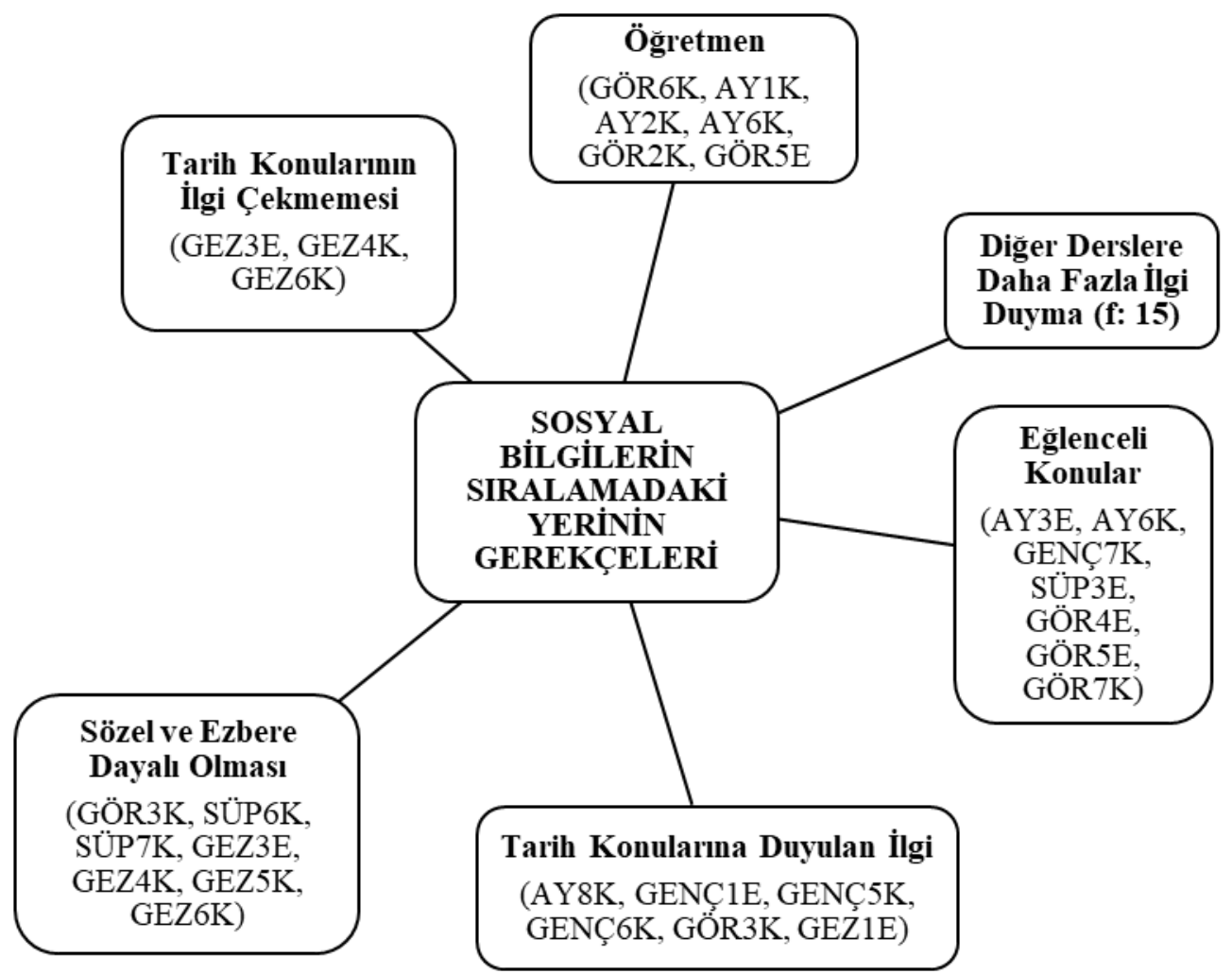

Öğrencilerin ön odak grup görüşmesinde çok sevilen dersler sıralamasında sosyal bilgiler dersinin yerini belirleme gerekçelerine bakıldığında; diğer derslere daha fazla ilgi duymaları, sosyal bilgiler dersinin sözel ve ezbere dayanan nitelikte olması, tarih konularını sevme veya sevmeme, eğlenceli konular ve öğretmen faktörü gelmektedir. Sözel ve ezbere dayalı olması kategorisinde öğrenciler anlatılan konuların çok soyut ve karışık olduğunu ve bu nedenle öğrenmekte zorluk yaşadıklarını belirtmişlerdir. $\mathrm{Bu}$ kategoride yer alan öğrencilerin görüşlerinden bir örnek şu şekildedir:

"Bana göre 4. strada. Tarih olduğu için ezber gerekiyor. Ezberlemek zor diğerlerinde işlemleri aklında tutuyorsun ama bunda zor. Geçen sene de anlamadım tarih konularını." (GEZ3E). 
Tablo 1 incelendiğinde uygulamalar öncesinde sosyal bilgiler dersini 3., 4., ve 5. sıraya koyan ve toplam öğrencilerin \%72'sini oluşturan öğrenciler, uygulamalar sonrasında çok sevilen dersler sıralamasında sosyal bilgiler dersini 1 . ve 2 . sıraya koymuşlardır. Bununla birlikte uygulama öncesinde sosyal bilgiler dersini 1. ve 2 . sıraya koyan ve \%27.77'ye tekabül eden öğrencilerin oranı, uygulama sonrasında \% 100 olmuştur. Öğrencilerin uygulama sonrasında sosyal bilgiler dersinin sıralamasında meydana gelen olumlu yönde değişikliğin nedenlerine yönelik görüşleri Diyagram 5 'te verilmiştir.

Diyagram 5. Son Odak Grup Görüşmesi Sosyal Bilgiler Dersinin Sevilen Dersler Sıralamasındaki Yerinin Gerekçeleri

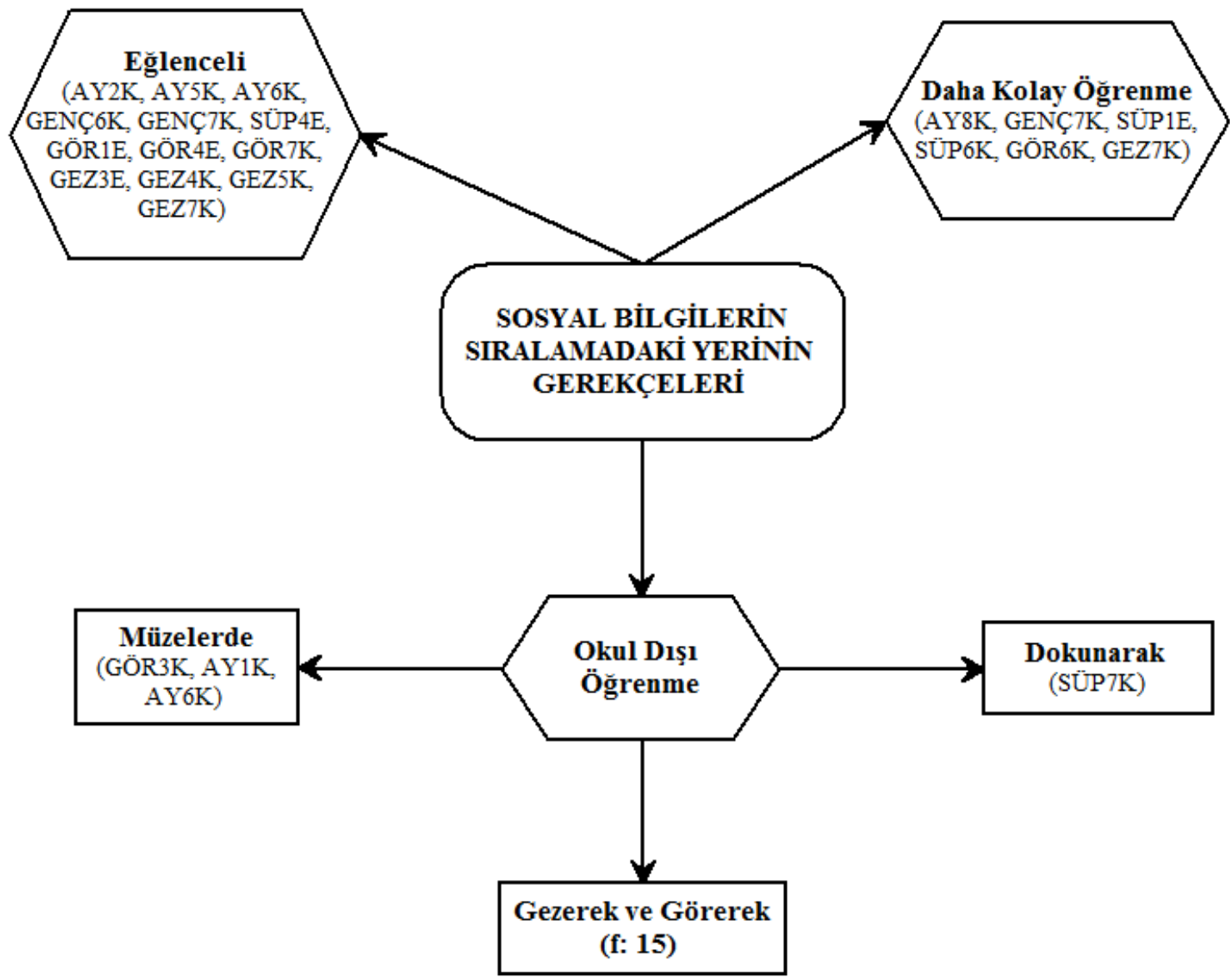

Diyagram 5 incelendiğinde öğrencilerin sevilen dersler sıralamasında sosyal bilgiler dersini ön sıralarda söylemelerinin gerekçeleri üç ana kategoride toplanmıştır. Okul dışı öğrenme kategorisinde öğrenciler okulun dışında gezerek, görerek, dokunarak, müzelerde ders işlemekle daha iyi öğrendiklerini ve dersi daha çok sevdiklerini belirtmektedir. AY5K kodlu öğrenci bu konuda şöyle demektedir:

"Eskiden sosyal bilgiler dersi 2. sıradaydı şimdi l'e yükseldi. Çünkü eskiden dört duvar arasında işlerdik ama şimdi hayatın içinde işliyoruz. Yerinde öğrenip görüyoruz. Bir nevi eğlenerek öğreniyoruz. Hep aynı yerdeyiz, aynı şeyleri görüyoruz farklı şeyler olmuyordu. Bu etkinliklere başladığımızdan beri sosyal bilgiler dersi daha eğlenceli geliyor." (AY5K).

Öğrenciler müzeler ve tarihi mekânlarda öğrenmenin yanı sıra uygulamaların eğlenceli olmasına vurgu yaparak etkinliklerde hiç sıkılmadıklarını dile getirmişlerdir: 
"Birinci sırada. Diğer derslerde sıkıldım artık. Hep aynı konu hep aynı şeyin üstünde duruyorlar. Hem de dişarı gidecek bir şey de yok. En azından sosyal bilgiler dersinde demek ki varmış. Bana önceden Sultan Camisi neresi diye sorsaydınız daha önce hiç gitmemiştim. Bu gezilerle ilk defa gördüm.” (AY2K).

Öğrenciler etkinliklerle birlikte dersi daha kolay öğrendiklerini ve öğrendiklerinin daha kalıcı olduğunu vurgulamışlardır. Bu nedenle sıralamada ön sıraya yükseldiğini belirtmişlerdir. Öğrencilerin sosyal bilgiler dersine bakış açılarının değişiminin bir örneği olarak GEZ5K kodlu öğrencinin uygulamalar öncesi ve sonrası görüşleri birlikte verilmiştir:

"Sıralamada beşinci sırada. Sosyal bilgilerde pekiyi değilim çünkü ezberim çok kötü olduğu için çoğu şeyi ezberleyemiyorum. Ezberleyemediğim için notum düşüyor ve dersten soğuyorum. Her ne kadar çalışsam da olmuyor.” (GEZ5K ön odak grup görüşmesi)

"Siralamada 1. sırada; çünkü çok eğlenceli geçiyor. Uygulamalardan önce sonuncu stralarda yer alıyordu." (GEZ5K son odak grup görüşmesi).

Öğrencilerin ön odak grup görüşmelerinden elde edilen verilere göre sosyal bilgiler dersinde işlenen konular içerisinde sevdikleri ve sevmedikleri konular sırasıyla Diyagram 6 ve Diyagram 7'de gösterilmiştir.

Diyagram 6. Uygulamalar Öncesi Sosyal Bilgiler Dersinde Çok Sevilen Konular

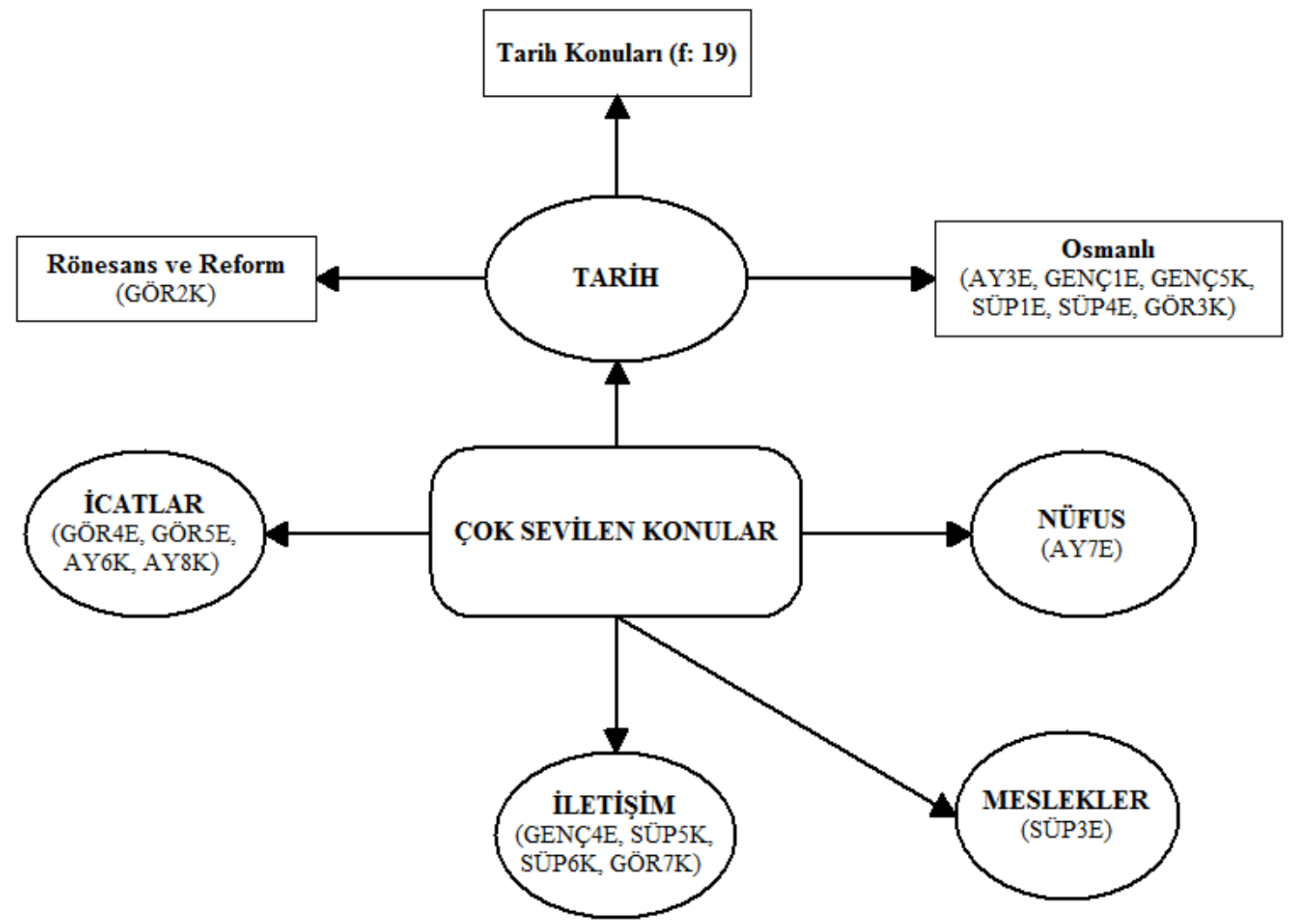

Diyagram 6 incelendiğinde öğrencilerin sosyal bilgiler dersinde çok sevdikleri konuların başında tarih konuları geldiği görülmektedir. Öğrenciler ilk defa 7. sınıfta gördükleri Osmanlı tarihini çok sevdiklerini belirtmişlerdir. Öğrencilerin bir kısmı ise Türk tarihini işlemekten zevk aldıklarını, geçmişte yaşanan olayları merak ettiklerini ve atalarımızla ilgili bilgiler edinmekten hoşlandıklarını belirtmişlerdir. Öğrenciler çok 
sevilen konular arasında 7. sınıf sosyal bilgiler dersinin ilk ünitesinde yer alan iletişim, ikinci ünitesinde yer alan nüfus ve dördüncü ünitesinde yer alan icatlar konularını belirtmişlerdir. Öğrenciler, bu konuları seçme nedeni olarak ilgilerini çekmesi ve daha kolay anlamalarını sağlamasını göstermektedir.

Diyagram 7. Uygulamalar Öncesi Sosyal Bilgiler Dersinde Sevilmeyen Konular

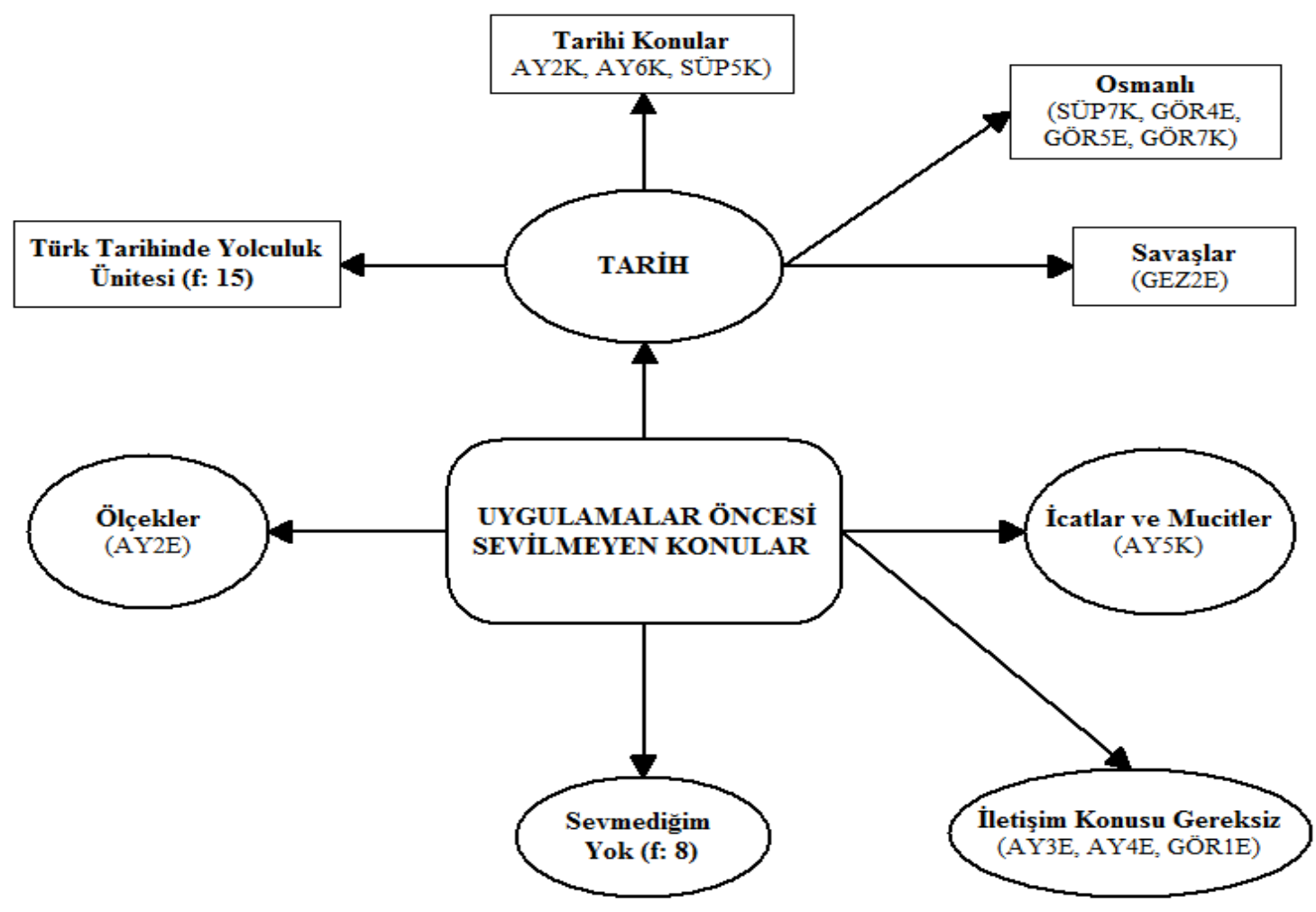

Uygulamalar öncesi öğrencilerin sosyal bilgiler dersinde sevmedikleri konulara bakıldığında tarih kategorisinin en başta geldiği görülmektedir. Öğrenciler en fazla Türk tarihinde yolculuk ünitesinde zorlandıklarını belirtmişlerdir. Bu ünite konularının çok karışık olduğunu ve tarih konularını anlamakta güçlük yaşadıklarını belirtmişlerdir. Öğrenciler bir diğer neden olarak tarih konularında kişi adları ve tarihleri akılda tutmada zorlandıklarını beyan etmişlerdir. Aşağıda tarih konularının sevilmeme nedenleriyle ilgili doğrudan alıntılar verilmiştir:

“Türk tarihi konusu zor geliyor. Diğerleri daha kolay anlaşıllyor. Bu konudan sıkllyorum çünkü ezberlemem gerekiyor. Türk tarihinde yolculuk ünitesinde isimler çok fazla var.” (GEZ3E).

AY2K kodlu öğrenci ise tarih konularını sevmeme nedeni olarak bu konuların ilgisini çekmemesinin yanı sıra öğrendiği tarihi bilgilerin günlük hayatında hiçbir işine yaramayacağını belirtmektedir:

"Tarih konularını sevmiyorum. Banane bunlardan diyorum. Benim ne işime yarayacak diyorum.” (AY2K).

AY2K kodlu öğrencinin görüşleri Alazzi \& Chiodo (2004), Byford (2002), Clarke \& Lee (2004), Çetin (2016), Harrison (2012) ve Mitchell ve Elwood (2012) tarafından yapılan çalışmalarla uyumludur. Bu çalışmaların tamamında tarih konuları, öğrenciler tarafından "sıkıcı ve ezber gerektiren” şeklinde algılanmaktadır. Açıkalın'a 
(2017) göre öğrencilerin bu şekilde algılamalarının nedeni; sosyal bilgiler ve tarih derslerinde öğrencilere aktarılan bilgilerin çoğunlukla ezber gerektirmesi ve öğrencilerin bu bilgiler ile tarihsel olayların geçtiği mekânlar arasında bağlantı kuramamasıdır.

Tarih konularının hem çok sevilen hem de sevilmeyen konular içerisinde yer alması dikkat çekicidir. Bu durumun pek çok farklı nedeni olmakla birlikte öğrencilerin tarihe yönelik kişisel ilgi ve meraklarının farklılaştığı yorumu yapılabilir. F14 kodlu öğrenci ise zaman içinde bilim ünitesinde yer alan icatlar ve mucitlerin isimlerini aklında tutmakta zorlanması nedeniyle bu konuları sevmediğini dile getirmiştir. İletişim konusunun çok basit olduğu ve seviyelerinin altında yer aldığına dikkat çeken öğrenciler bu ünitenin çok gereksiz olduğunu ve kaldırılmasını istemektedir. İcatlar ve iletişim konularının çok sevilen konular arasında da yer aldığı görülmektedir. Bu durumda sınıftaki öğrencilerin uygulamalar öncesinde sosyal bilgilere yönelik algıları arasında uyumsuzlukların olduğu ve sosyal bilgiler algılarının heterojen bir yapıda olduğu yorumu yapılabilir. Bazı öğrenciler ise (f: 8) sosyal bilgiler konuları arasında sevmedikleri veya anlamakta zorlandıkları herhangi bir konu bulunmadığını beyan etmişlerdir.

Uygulamalar neticesinde tarih konularına yönelik yoğun bir öğrenme sürecine giren öğrencilerin tarihe olan bakış açıları olumlu yönde değişmiştir. Okul dışında gezerek, görerek, dokunarak bizzat tarihi mekânlarda ve müzelerde ders işleyen öğrenciler için tarih konuları somutlaşmaya başlamıştır. Öğrenciler uygulamalarda geçirdikleri eğlenceli anları hatırladıkça tarih konularının sıkıcı olmayan yönünü de keşfetmişlerdir. Öğrencilerin sosyal bilgiler konularına -özellikle de tarih- yönelik algılarının nasıl ve ne yönde değiştiğini ortaya koymak amacıyla uygulamalar sonrasında yapılan odak grup görüşmesinde öğrencilerden sosyal bilgiler derslerinde çok sevdikleri konuları nedenleriyle birlikte açıklamaları istenmiştir. Diyagram 8'de öğrencilerin uygulamalar sonrasında sosyal bilgiler dersinde çok sevdikleri konular yer almaktadir. 
Diyagram 8. Uygulamalardan Sonra Sosyal Bilgiler Dersinde En Çok Sevilen Konular

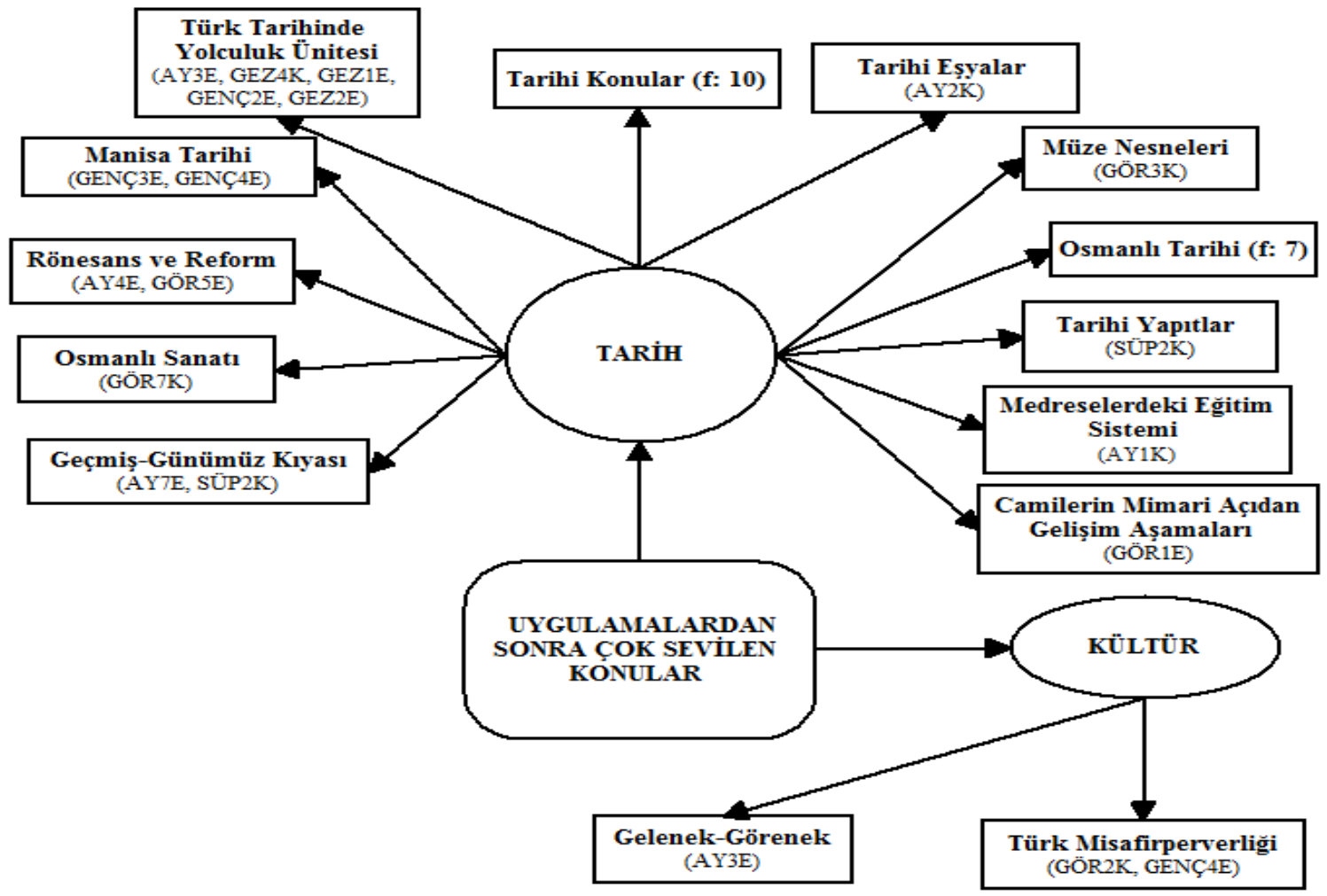

Diyagram 8 incelendiğinde öğrencilerin sosyal bilgiler derslerinde çok sevdikleri konuların tarih ve kültür ana kategorileri altında toplandığı görülmektedir. Bununla birlikte sosyal bilgileri oluşturan diğer disiplin dallarına yönelik konuların (coğrafya, ekonomi, hukuk, vatandaşlık, vb.) öğrenciler tarafından dile getirilmemesi; öğrencilerin uygulamaların etkisinde kaldıkları ve yapılan etkinlikleri benimsedikleri şeklinde yorumlanabilir. Uygulamalardan önce çok sevilen konular arasında yer alan iletişim, nüfus ve icatlar konularının uygulamalar sonrasındaki odak grup görüşmelerinde bahsi geçmediği görülmektedir.

Ön odak grup görüşmelerinde tarih ana kategorisi içerisinde uygulamalara özgü kategoriler yer almazken; uygulamalar sonrasında Manisa tarihi, tarihi yapttlar, müze nesneleri, tarihi eşyalar, medreselerdeki eğitim sistemi, camilerin mimari açıdan gelişim aşamaları, Osmanlı sanatı ve geçmiş-günümüz kıyaslaması kategorileri ortaya çıkmıştır. Öğrenciler ön odak grup görüşmesindeki genelleyici konuşmalarının aksine son odak grup görüşmesinde çok sevdikleri konuları daha fazla ayrıntıya girerek anlatmışlardır. Aynı şekilde çok sevilen konuların seçilme nedenlerinin açıklanmasında da son odak grup görüşmesinde daha ayrıntılı bilgiler vermişlerdir. Aşağıda öğrencilerin tarih konularını çok sevme nedenleriyle ilgili doğrudan alıntı yer almaktadır:

"Etkinlikleri yapmadan önce tarihi pek sevmiyordum. Çünkü tarihi olaylart akılda tutması zor oluyordu; ama etkinlikleri yaptıktan sonra tarihe daha fazla ilgim arttı. Eskiden neymişiz şimdi ne olduk gibisinden. Manisa Müzesi'nde Osmanlıdan kalan eşyaları ve oradaki estetiği ve güzelliği gördük. Tarihi daha çok seviyorum artık." (SÜP4E).

Yukarıdaki alıntı, tarihi mekânlar ve müzelerde görerek ders işlemenin öğrencilerin tarih algılarını olumlu yönde değiştirdiğini göstermektedir. Öğrenciler etkinliklerle ders işlerken daha çok eğlendiklerini ve bunun sonucunda daha kolay 
anladıklarını dile getirmişlerdir. Bazı öğrenciler ise genel Türk tarihinden ziyade Manisa'nın yerel tarihine daha fazla ilgi duyduklarını belirtmiştir. Bu duruma M6 kodlu öğrenciden alınan alıntı örnek gösterilebilir:

"Türk tarihi değil de Manisa'nın tarihi daha çok ilgimi çekti; çünkü Kanuni Sultan Süleyman, Lidyalılar ve diğerleri olsun daha çok ilgimi çekti. Yaptıkları şeyler büyük adımlar." (GEZ1E).

Uygulamaların Manisa'nın yerel tarihine odaklanması, öğrencilerin kimlik ve aidiyet duygularının gelişerek bizzat içinde yaşadıkları kente başka bir gözle bakmalarını sağlamıştır. Bu durumun sonucunda öğrenciler belki de hiç gidip göremeyecekleri yerlerin bilgisini edinmektense, yerel farkındalık geliştirerek yaşadıkları bölgenin tarihi ve kültürel özelliklerini daha yakından tanıma fırsatı yakalamışlardır. Geçmiş-günümüz karşılaştırması kategorisinde yer alan öğrenciler, geçmişin maddi kanıtlarıyla yüzleşip günümüzdeki muadilleriyle benzer ve farklı yönlerini bulmaktan hoşlandıklarını dile getirmişlerdir. AY4E kodlu öğrenci ise sosyal bilgiler dersinde çok sevdiği konuyu anlatırken tamamen uygulamalardan bahsetmiştir:

"Osmanlı tarihi, Osmanlı tarihinin içinde de camilerin gelişimi hoşuma gidiyor. Mesela Ulu camiyi yapmışlar kilisenin kalıntılarından, daha sonra Sultan camisini yapmışlar ondan daha güzel olarak ve en sonunda da Muradiye camisini yapmışlar. Camilerdeki değişimi görmek hoşuma gidiyor.” (AY4E).

Yukarıdaki alıntıdan öğrencinin içinde yaşadığı kentin simgeleri haline gelen tarihi üç camiyi birbiriyle kıyasladığı ve zamanla birlikte değişim ve sürekliliğin farkına vardığ1 görülmektedir. GÖR5E kodlu öğrenci ise tarih konularını sevmiyorken tarihi eserleri bizzat yerinde gördüğü için fikrinin değiştiğini belirtmektedir:

"Osmanlı tarihi ilgimi çekiyor; çünkü tarihi eserleri seviyorum. Etkinliklerden önce Osmanlı tarihini sevmiyordum. Tarihi eserleri kendim gezip gördüğ̈̈m için fikrim değişti." (GÖR5E).

Öğrenciler uygulamalarda Osmanlı kültür ve sanatına yönelik çok fazla etkinlik yaptıkları için bu konuları sevdiklerini dile getirmişlerdir. Yukarıdaki açıklamaların genelinden öğrencilerin uygulamalardan önce tarih konularını çok fazla sevmeyip soyut bulmalarına rağmen uygulamalarla birlikte tarihe olan ilgilerinin arttığı ve tarih konularını daha fazla sevmeye başladıkları sonucu çıkarılabilir.

Uygulamalardan önce sosyal bilgiler dersinin işlenişine yönelik öğrencilerin görüşlerini almak amacıyla öğrencilere "Sosyal bilgiler dersinin işlenişi hakkında neler düşünüyorsunuz? Size göre sosyal bilgiler dersi daha iyi nasıl işlenebilir?” sorusu yöneltilmiştir. Öğrencilerin uygulamalar öncesi sosyal bilgiler dersinin daha iyi işlenmesiyle ilgili görüşleri Diyagram 9'da gösterilmiştir. 
Diyagram 9. Uygulama Öncesi Dersin İşlenişine Yönelik Öğrenci Görüşleri

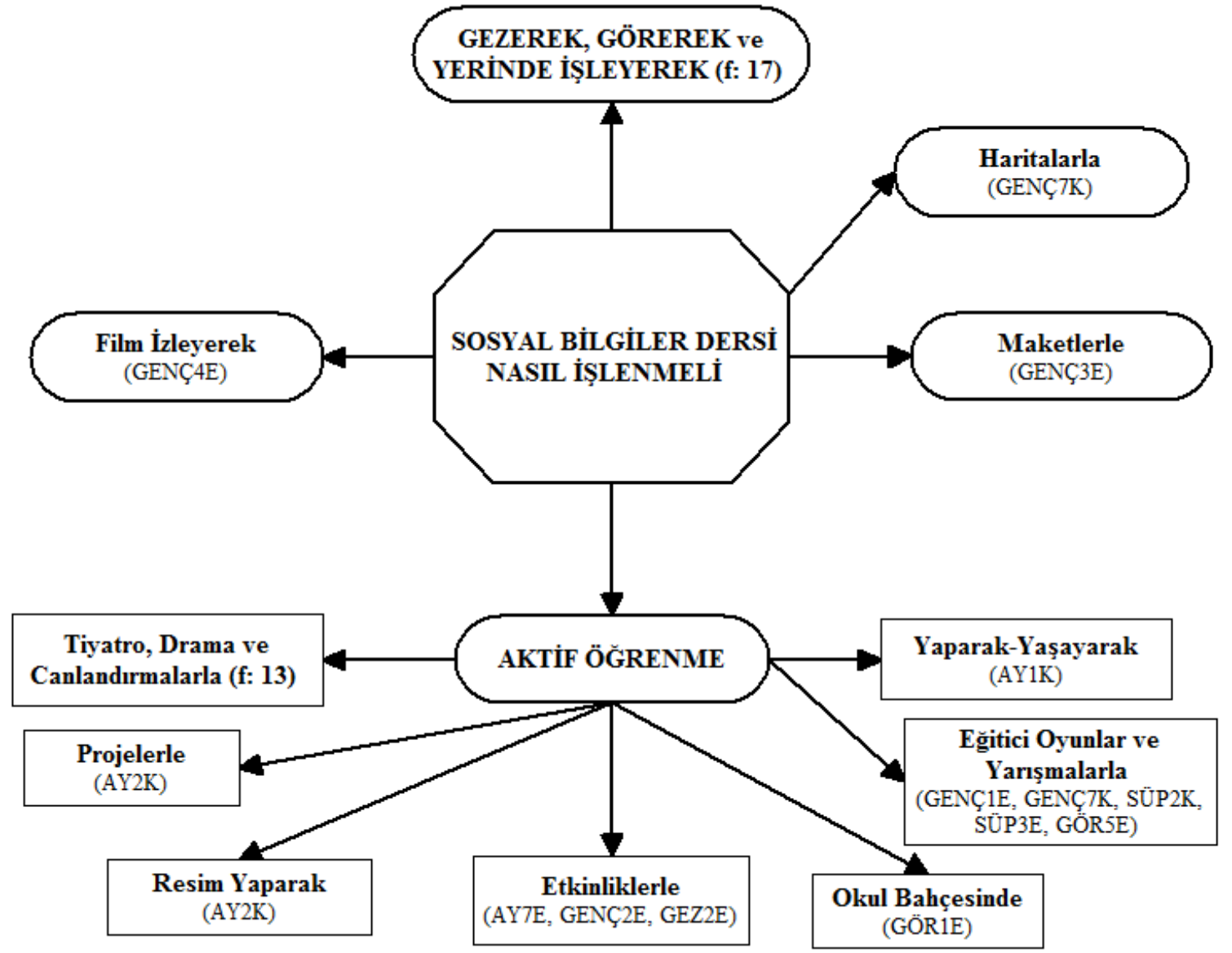

Diyagram 9 incelendiğinde öğrencilerin sosyal bilgiler dersinin daha iyi işlenmesine yönelik görüşlerinin aktif ögrenme ve gezerek, görerek ve yerinde işleyerek kategorilerinde yoğunlaştığı görülmektedir. Öğrencilerin öğretmen ve kitap merkezli klasik eğitim anlayışını benimsemedikleri ortadadır. Derste aktif biçimde rol alan öğrenciler konuları daha kolay anladıklarını belirtmiştir. Öğrencilerin aktif öğrenme kategorisinde tiyatro, drama ve canlandırmalara çok fazla değindiği görülmektedir. Bilginin pasif alıcısı olmaktan ziyade bilgiyi kendi zihninde kurarak öğrenen öğrenciler için eğitici oyunlar, resim yapma ve projeler önemli yer tutmaktadır.

Uygulamalarla birlikte öğrenciler gezerek, görerek, dokunarak, hissederek, yaparak ve yaşayarak çeşitli etkinlikler yapmışlardır. Okul öğrenmelerinden tamamen farklı olan bu etkinliklerde öğrenciler yaşantı temelli öğrenme sürecine girerek hem duyuşsal hem de bilişsel açıdan doyum sağlamışlardır. Uygulama sonrasında öğrencilere sosyal bilgiler dersi daha iyi nasıl işlenebilir sorusu tekrar sorulmuştur. Öğrencilerin uygulama sonrasındaki görüşlerine göre oluşturulan Diyagram 10'da sosyal bilgiler dersinin daha iyi işlenebilmesi için çeşitli öneriler yer almaktadır. 
Diyagram 10. Uygulama Sonrası Dersin İşlenişine Yönelik Öğrenci Görüşleri

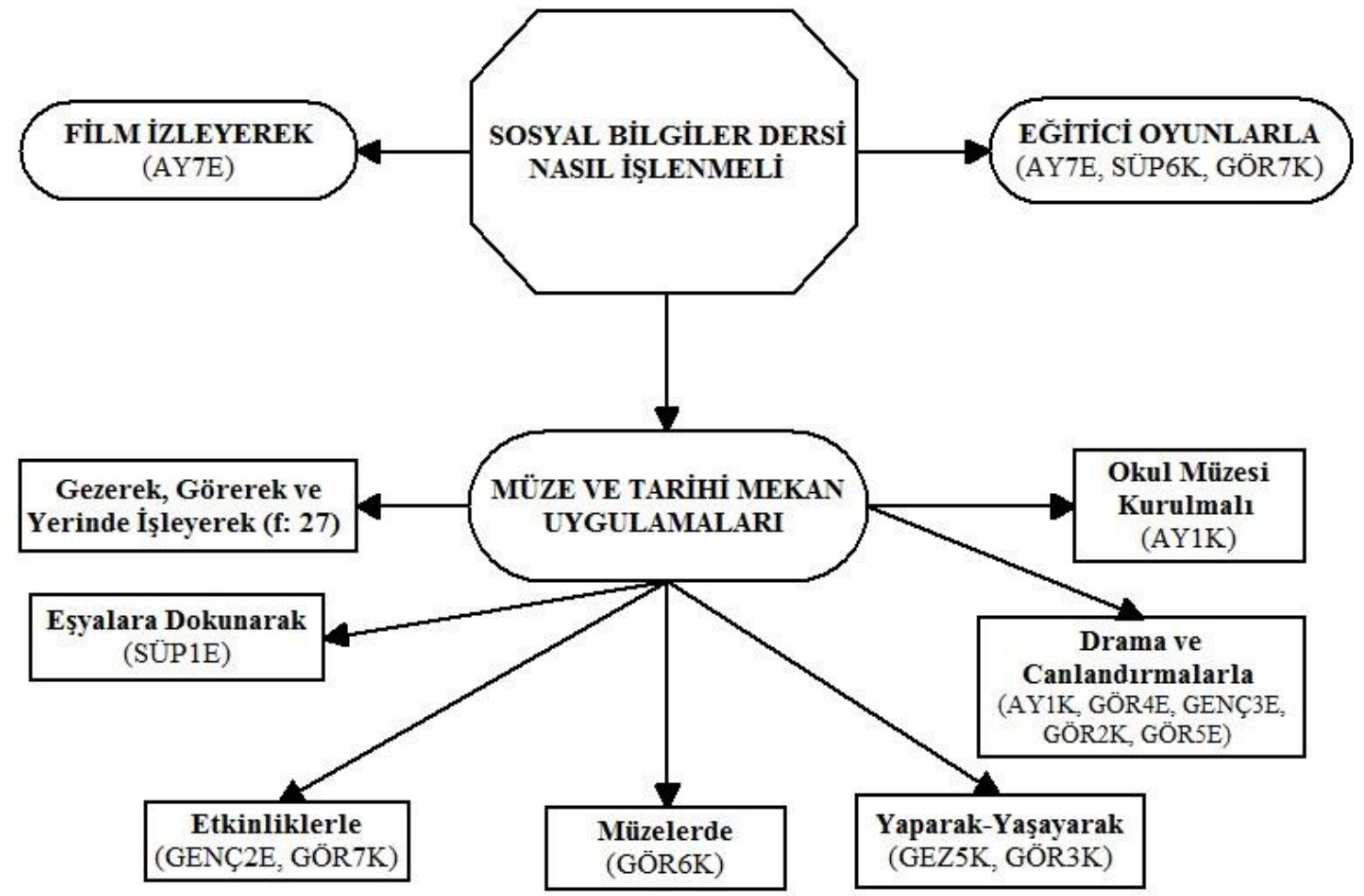

Öğrencilerin çok büyük bir kısmı, sosyal bilgiler derslerinin müzelerde ve tarihi mekânlarda işlenmesi gerektiğini belirtmişlerdir. Bu sonuç, uygulamaların öğrencileri olumlu yönde etkilediği şeklinde yorumlanabilir. Gezerek, görerek ve yerinde işleyerek kategorisinin çok sık dile getirildiği gözlenmektedir. Bu kategoriyle ilgili öğrenci alıntıları aşağıda verilmişstir:

"Görerek işlenmelidir; çünkü yazarak ve okuyarak bir şey anlamıyoruz. Orayı görüyoruz ve tarih kokusunu içimize çekiyoruz ve daha iyi oluyor." (SÜP5K).

Okulun dişına çıkarak geziler yapmak, rutin faaliyetin dişında yapılan bir durum olması nedeniyle öğrenciler bu etkinliklere karşı çok ilgilidir. Sınıfta dört duvar arasından kurtulup gezi yaptıkları için öğrenciler doğal olarak memnundur. Burada asıl önemli olan nokta, öğrencilerin müze ve tarihi mekân uygulamalarının eğitimsel değerine yönelik görüş belirtmeleridir. Öğrenciler uygulamalarla birlikte bizzat yerinde ders işleyip sosyal bilgiler dersini daha iyi anladıklarını ve öğrendikleri bilgilerin daha kalıcı olduğunu vurgulamaktadır.

Uygulamalar öncesinde öğrencilerin sosyal bilgiler algılarını daha ayrıntılı bir şekilde çözümlemek amacıyla "Sosyal bilgiler derslerinde öğrendikleriniz günlük hayatınızda işinize yarıyor mu?" sorusu yöneltilmiştir. Öğrencilerin uygulamalar öncesinde sosyal bilgiler konularını günlük hayatta kullanabilme durumları Diyagram 11 'de gösterilmiştir. 
Diyagram 11. Uygulamalar Öncesi Sosyal Bilgiler Konularının Günlük Hayatta Kullanılma Durumları

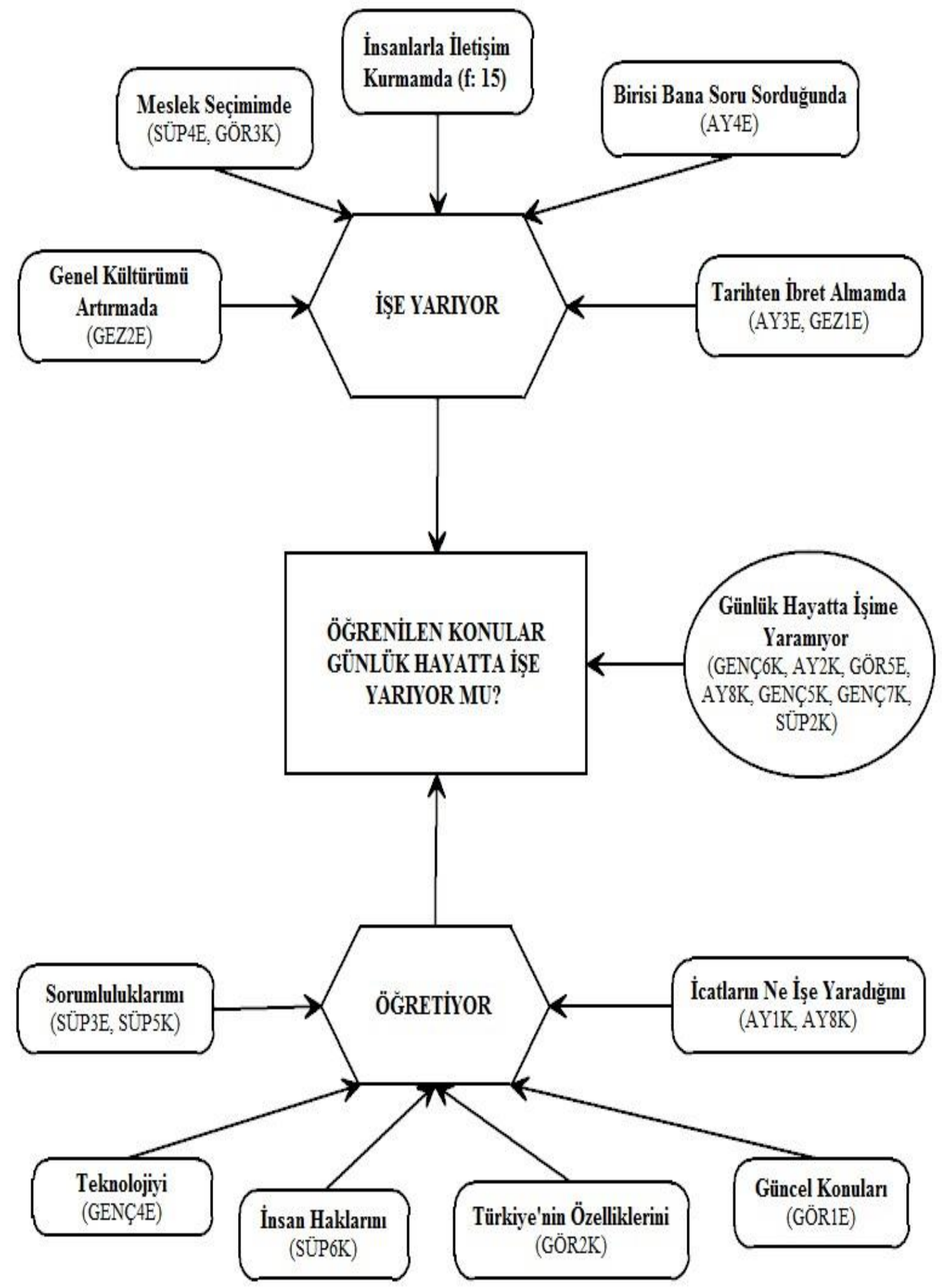

Diyagram 11'de görüleceği üzere öğrencilerin büyük bir kısmı sosyal bilgiler dersinde öğrendikleri bilgileri günlük hayatlarında kullanabildiklerini belirtmişlerdir. Özellikle 7. sınıf sosyal bilgiler dersinin birinci ünitesi iletişim ve insan ilişkileri konusunun günlük hayatta çok fazla kullanıldığı öğrenciler tarafından dile getirilmiştir. Bununla birlikte günlük hayatta kullanılma kategorilerine bakıldığında tarih disiplinine yönelik bir kategorinin olmadığı görülmektedir. İki öğrenci tarihten ibret aldıklarını 
beyan etmişlerdir. Günlük hayatta kullanmıyorum diyenlerin tamamına yakını tarih konularının günlük hayatta bir işlerine yaramadığını beyan etmişlerdir.

Uygulamalarla birlikte günlük hayatında her zaman görüp yakınından geçtiği, adını çok fazla işittiği ama asıl işlev ve önemini fazla bilmediği Manisa'nın tarihi mekânları ve müzelerine yönelik yoğun bir etkinlik sürecinden geçen öğrencilere bu uygulamalardan edindikleri bilgi ve becerilerin günlük hayatta işlerine yarayıp yaramayacağı sorulmuştur. Öğrencilere göre, uygulamalar neticesinde öğrenilen bilgi ve becerilerin günlük hayatta kullanabilme durumları Diyagram 12'de gösterilmiştir.

Diyagram 12. Öğrenilen Bilgi ve Becerilerin Günlük Hayatta Kullanabilme Durumları

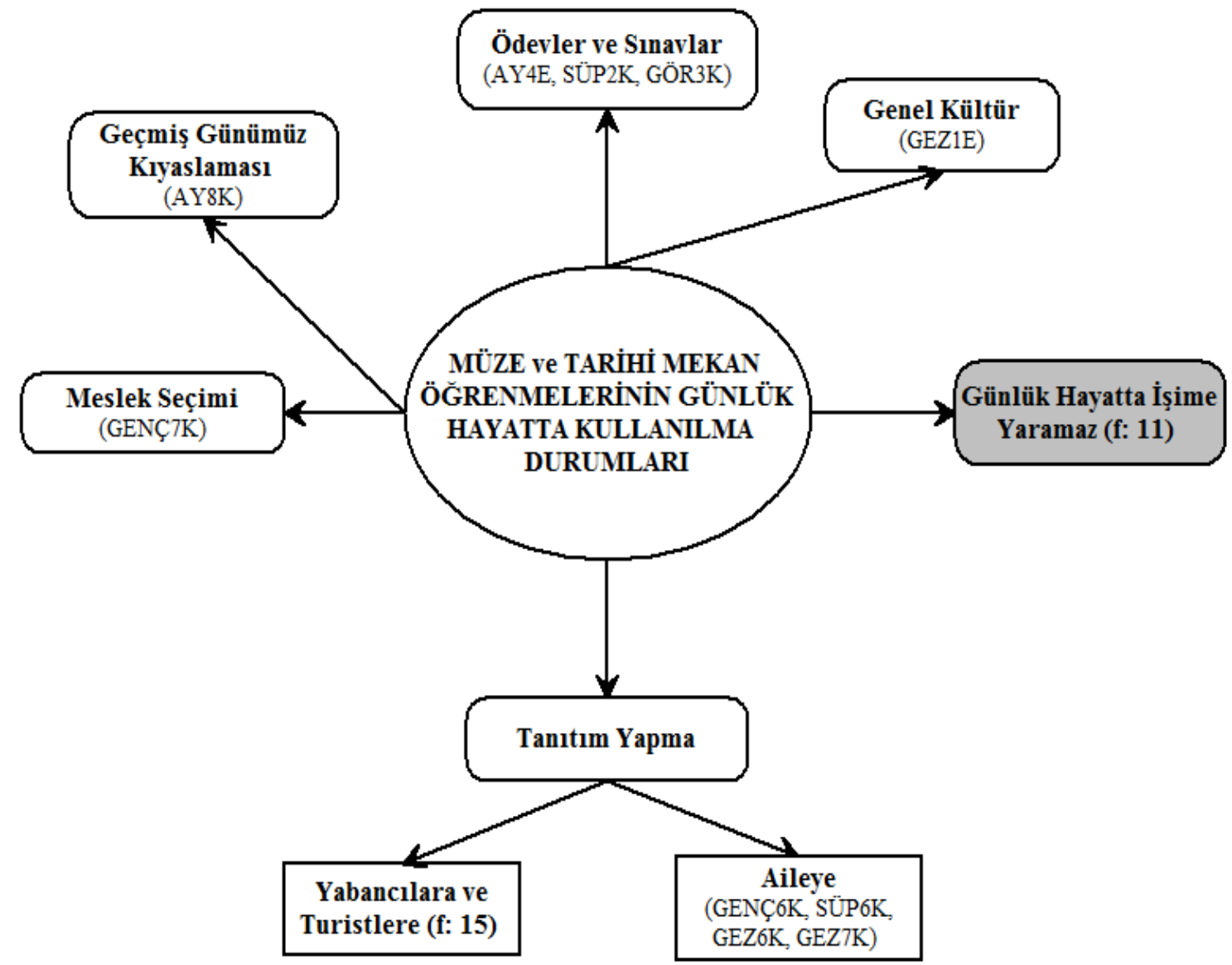

Buna göre öğrenciler Manisa'nın tarihi mekânları ve müzelerinde öğrendikleri bilgi ve becerileri günlük hayatlarında; Manisa'nın tanıtımını yapmada, ödev ve sınavlarında, geçmişten ibret alarak hayatlarını şekillendirmede, geçmişle günümüzü karşılaştırmada, genel kültürlerini artırmada ve meslek seçiminde kullanabileceklerini belirtmişlerdir.

Tanıtım yapma kategorisinde öğrenciler daha önce buna benzer herhangi bir deneyim yaşamadıkları için edindikleri bilgi ve becerileri başkalarıyla paylaşma ve duygularını dile getirme hevesinde oldukları yorumu yapılabilir. Bu duruma örnek olarak aşağıda doğrudan alıntılar verilmiştir:

"Günlük hayatımda kullanırım. Dünyadaki dört ayak izinden birinin Manisa Müzesi'nde olduğunu kullanarak herkese hava atardım.” (AY3E).

AY3E kodlu öğrencinin Manisa Müzesi’ne gitmeyi, orada eski insan ayak izlerini görmeyi bir ayrıcalık olarak algıladığı görülmektedir. Hâlbuki müzeler her 
kesimden insanın ziyaretine açıktır. Müzelerde sergilenen eserleri görmek, sadece şanslı azınlıklara veya elit kesime özgü bir durum olmamalıdır. Öğrenciler aileleriyle birlikte boş zaman etkinliklerinde müzeler ve tarihi mekânları gezip bu yerlere yönelik bilgi ve farkındalıklarını arttırmaları halinde bu durumu normal karşılayacak; çünkü müzelerde sergilenen eserlerden herkesin haberi olacaktır. Bu durumla ilgili bir diğer dikkat çekici nokta, aileye anlatma alt kategorisidir. $\mathrm{Bu}$ kategorinin ortaya çıkması; velilerin Manisa'nın müzeleri, tarihi mekânları ve kültürel özelliklerinin farkında olmadıkları ve bu yerlere gitmedikleri şeklinde yorumlanabilir. Öğrenciler uygulamalar sayesinde geçmişle günümüz koşullarını karşılaştırabildiklerini ve geçmişten ibret alarak günlük yaşamlarında uyguladıklarını belirtmişlerdir.

Öğrencilerin bir kısmı ise uygulamalarda öğrendikleri bilgi ve becerilerin günlük hayatta pek işlerine yaramayacağını dile getirmiştir. Bu duruma örnek olarak SÜP3E kodlu öğrencinin görüşleri ile GÖR5E kodlu öğrencinin günlüğüne yazdığı notlar aşağıdaki gibidir:

"Okul hayatımda işime yarar; ama günlük hayatımda bir işime yaramaz." (SÜP3E).

"Kula evlerinin o zamanki bir yanardă̆ patlamass sonucu lavın donarak taşlaşmasından yararlanarak o taşlardan yapılmış olması, bazı evlerin bodrumlarının ahır olarak kullanılması ve altından atlıların geçebilmesi için cumbaların daha yüksekte bulunması iyi bilgiler hakikaten. Genel kültür için bilmek lazım bence; ama maalesef ki günlük hayatımda işe yaramayacak.” (GÖR5E Öğrenci Günlüğü).

Buna benzer düşüncedeki öğrencilerin böyle düşünmelerinin sebeplerine bakıldığında; uygulamalarda edindikleri bilgileri okul öğrenmeleriyle özdeş tutarak günlük hayatla okulu farklı şeyler olarak algılamaları ve günlük hayat kavramının içerisine tarihi ve kültürel özellikleri dâhil etmemeleri gösterilebilir.

\section{Tartışma ve Sonuç}

Uygulamalar neticesinde öğrencilerin sosyal bilgiler dersine yönelik algılarında önemli değişiklikler ortaya çıkmıştır. Uygulamalardan önce öğrencilerin sosyal bilgiler algılarında coğrafya, hukuk ve küresel bağlantılar gibi kategoriler yer alırken; uygulama sonunda öğrencilerin sosyal bilgiler algılarında bu kategoriler yerini müze ve tarihi mekân uygulamaları ana kategorisi altında müzeler, camiler, tarihi mekânlar, mezarlıklar medrese ve külliyeler, eğlence ve müze nesneleri gibi kategorilere bırakmıştır. Uygulamalar öncesinde sosyal bilgiler algısının tarih kategorisi içerisinde yer alan Rönesans, uygarlıklar ve tarihi şahsiyetler gibi kategoriler uygulama sonrasında yerini tarihi yaptlar, tarihsel empati ve tarihi eşyalar kategorilerine bırakmıştır. Bu sonuç müze ve tarihi mekân uygulamalarının, öğrencilerin tarih algıları üzerinde değişmelere yol açtığını göstermektedir. Dönmez ve Yeşilbursa (2014) tarafından ortaokul öğrencilerinin tarih algılarını ortaya koymak amaciyla yapılan çalışmada, katılımcıların tarihi en çok geçmişteki olaylar kategorisi altında siyasi tarih konuları olan savaşlar, barışlar, antlaşmalar ve uygarlıklar şeklinde algıladıkları görülmüştür. Dönmez ve Yeşilbursa'nın (2014) bulduğu bu sonuçlar; mevcut araştırmanın uygulamalar öncesinde yapılan ön odak grup görüşmelerinden ortaya çıkan tarih algılarıyla uyumluluk göstermektedir. Buna göre uygulamalar öncesinde öğrencilerin tarih algısı "siyasi ve resmi tarih" kategorileri kısmında ağır basarken; uygulamalar sonrasında bu durum yerel tarih ve kültürel öğeler özelinde "müzeler ve 
tarihi mekânlar" lehine değişmiştir. Sosyal bilgileri günlük hayatla özdeşleştiren öğrencilerin sayısı uygulama öncesine göre dikkat çekici bir biçimde artmıştır. Bu sonuçlar müze ve tarihi mekân uygulamalarının öğrencilerin sosyal bilgilere yönelik algılarını istenilen yönde değiştirdiğini göstermektedir. Bu durumun ortaya çıkmasında öğrencilerin uygulamalar süresince yaşadıkları güzel ve eğlenceli anların etkisinin olduğu aşikârdır. Bununla birlikte uygulamalar öncesinde hiçbir öğrencinin sosyal bilgileri müzeler ve tarihi mekânlarla özdeşleştirmemesi göz önüne alındığında karşılaştırmalı sonuçlar uygulamaların işe yarayıp yaramadığı konusunda fikir vermesi açısından önemlidir.

Araştırmanın bir diğer sonucu ise çok sevilen dersler sıralamasında sosyal bilgilerin uygulama öncesi ve sonrası değişimidir. Uygulamalar öncesinde öğrencilerin \% 72'lik kısmı sosyal bilgileri üç, dört ve beşinci sıraya koyarken; uygulama sonrasında öğrencilerin tamamı sosyal bilgiler dersini bir ve ikinci sıraya yerleştirmişlerdir. Yaşanan bu \% 72'lik değişim uygulamaların etkisinin bir sonucu olarak yorumlanabilir. Şekil ve nicelik açısından ortaya konulan bu sonucun nedenleri incelendiğinde aşağıdaki sonuçlar ortaya çıkmaktadır. Öğrenciler uygulama öncesinde sözel ve ezbere dayalı olması ile tarih konularının ilgilerini çekmemesi gibi nedenlerle sosyal bilgiler dersinin sıralamada sonlarda yer aldığını belirtmişlerdir. Araştırmanın bu sonucu; alanyazındaki çalışmalarla (Alazzi \& Chiodo, 2004; Byford, 2002; Clarke \& Lee, 2004; Çetin, 2016; Harrison, 2012; Mitchell \& Elwood, 2012; Özkal, Güngör, \& Çetingöz, 2004) benzerlik göstermektedir. Fernandez, Massey \& Dornbusch (1975) tarafindan Amerika'daki lise öğrencileriyle yapılan çalışmada, öğrenciler sosyal bilgileri çok sıkıcı, günlük yaşamdan kopuk ve gelecekte pek fazla işlerine yaramayacak bilgilerden oluşan bir ders olarak algılamışlardır. Ayrıca bu öğrencilere matematik, İngilizce ve sosyal bilgiler dersleri arasında önem sırasına göre sıralama yapmaları istendiğinde sosyal bilgiler sonuncu sırada yer almıştır. Alazzi \& Chiodo (2004) tarafından Ürdün'deki 8. ve 11. sınıf öğrencileriyle yapılan nitel araştırmada hem ortaokul hem de lise öğrencileri sosyal bilgilerin önemli ve değerli bir ders olduğu algısına sahip olmalarına rağmen; öğrencilerden çok sevdikleri dersleri sıralamaları istendiğinde sosyal bilgilerin ön sıralarda yer almadığı görülmüştür. Uygulamalar sonrasında sosyal bilgiler dersinin çok sevilen dersler sıralamasında ilk iki sırada yer almasının nedenlerinin başında müze ve tarihi mekânlarda yapılan etkinlikler gelmektedir. Öğrencilerin en çok sevdiği dersin sosyal bilgiler olmasında; dersin müzeler ve tarihi mekânlarda görerek, gezerek, dokunarak eğlenceli bir biçimde işlenmesinin etkisi çok fazladır. Bu sonuçlar sosyal bilgiler ve tarihe yönelik duyuşsal açıdan meydana gelen olumlu yönde değişimler açısından benzer nitelikteki çalışmalarla (Aktekin, 2009; Avcı-Akçalı, 2013; Csikszentmihalyi \& Hermanson, 1995; Çerkez, 2011; Çulha, 2006; Demirboğa, 2010; Filiz, 2010; Güler, 2011; Işık, 2008; Meredith, Fortner \& Mullins, 1997; Nişanc1, 2010; Rix \& McSorley, 1999; Tuffy, 2011; Tunç-Şahin, 2011; Yazıcığlu, 2010; Wellington, 1990; Yorulmaz, 2016; Zayimoğlu-Öztürk, 2014) uyumludur.

Müze ve tarihi mekân uygulamalarından önce öğrencilerin sosyal bilgiler derslerinde çok sevdikleri konular içerisinde yer alan nüfus, iletişim, icatlar ve meslekler gibi konu başlıkları uygulamalar sonrasında yer almamıştır. Uygulamalar sonrasında öğrencilere sosyal bilgiler dersinde çok sevdiğiniz konular nelerdir diye sorulduğunda öğrenciler tarih kategorisi altında yer alan; Türk tarihinde yolculuk ünitesi, Manisa tarihi, tarihi eşyalar, müze nesneleri, tarihi yapıtlar, medreselerdeki 
eğitim sistemi ve camilerin mimari açıdan gelişim aşamaları alt kategorilerini söylemişlerdir. Bu kategoriler uygulama öncesinde yer almayıp tamamen uygulamalara özgü kategorilerdir. Bu durum öğrencilerin uygulamalar esnasında öğrendikleri konuları benimsediği anlamına gelmektedir. Bir diğer dikkat çekici nokta ise uygulamalar öncesinde öğrencilerin \%60'a yakını tarih konu başlığı altında yer alan Türk tarihinde yolculuk, Osmanlı devleti, savaşlar kategorilerini sevmediklerini beyan etmelerine rağmen; uygulamalar sonrasında bu kategorilerin çok sevilen konular arasında yer aldığı görülmektedir. $\mathrm{Bu}$ sonuçlar uygulamaların öğrencilerin tarih algısını olumlu yönde etkilediği şeklinde yorumlanabilir. Bir diğer sonuç ise uygulamalar öncesinde yer almayan gelenek-görenek ve Türk misafirperverliği kategorilerinin uygulamalar sonrasında ortaya çıkmasıdır. Kültür konu başlığı altında toplanan bu kategorilerin ortaya çıkması, öğrencilerin yerel ve kültürel tarihi önemseyip içselleştirmelerinde geliştirilen etkinliklerin işe yaradığını göstermesi açısından önemlidir.

Araştırmanın bir diğer sonucu ise müze ve tarihi mekânlarda öğrenilen bilgilerin öğrencilerin günlük hayatında işe yarayıp yaramadığı konusudur. Uygulama öncesi öğrencilerin; alanyazındaki benzer çalışmalarla (Alazzi \& Chiodo, 2004; Byford, 2002; Clarke \& Lee, 2004; Çetin, 2016; Harrison, 2012; Mitchell \& Elwood, 2012; Özkal ve diğerleri, 2004) uyumlu bir şekilde tarih konularını sevmedikleri ve günlük hayatlarında bir işlerine yaramadığı algısına sahip olduğu görülmüştür. Öğrenciler, uygulamalar esnasında öğrendikleri bilgilerin yabancılara, turistlere ve ailelerine Manisa'nın tanıtımını yaparken çok gerekli olacağını belirtmişlerdir. Bunun yanı sıra ödevlerde ve sınavlarda, meslek seçiminde, genel kültürlerini artırmada ve geçmişten ibret alıp günümüzdeki hayatlarını şekillendirmede; öğrendikleri bilgileri kullanabileceklerini beyan etmişlerdir. Öğrencilerin üçte biri ise müze ve tarihi mekânlarda öğrendikleri bilgileri günlük hayatlarında kullanamayacaklarını dile getirmiştir. Böyle düşünen öğrencilerin uygulamalarda edindikleri bilgileri okul öğrenmeleriyle bir tutarak günlük hayatla okulu değişik şeyler olarak algılamaları ve günlük hayat kavramının içerisine tarihi ve kültürel özellikleri katmamaları, bu durumun nedenleri arasında gösterilebilir. 


\section{Summary}

Purpose and Significance: The aim of this study is twofold. The first one is to practice the teaching activities designed to make use of museums and historical places within the context of grade seven social studies course. The second one is to reveal how and in which ways these activities have influenced students' perceptions of social studies. In order to enable students have meaningful and long lasting learning experiences in relation with historical topics located in the grade seven social studies curriculum, it is a must to make museums and historical places an ordinary component of school studies. In their conventional practice in social studies classes, teachers usually recite or explain historical topics that students have never come across before and probably may not be able to turn back in their future learning experiences. Such form of teaching makes students' learning too abstract, which is not related to their previous learning experiences or real lives.

On the other way, students learn by seeing, touching and smelling at museums and historical places. They can have opportunities to relate abstract information to concrete evidence, ask questions, draw pictures or illustrations, write about what they have seen or touch and enjoy all those processes. Students having difficulty in classroom teaching may have more efficient and durable learning experiences at museums and historical places by means of taking parts in historical enactments and role playing activities. The experiences may also help them to reveal their hidden talents (Seidel \& Hudson, 1999). Rather than unwillingly reciting abstract facts written in their history or social studies textbooks, students see and learn more by means of museum and historic places activities.

Method: Designed as an action research, the current study involves specifying a practice based or practice related problem occurring within the immediate environment of the researchers, formulating it as a research question, designing of an action plan, implementing the plan, assessing the processes of the implementation, evaluation of the whole process, and reformulation of the research question if seen necessary. The action research model has been chosen because it was seen as the most appropriate research model for the current study as one of the researchers teaching social studies in a public school experienced the difficulties and shortcomings stated above in his practice. 36 grade seven students (20 girls and 16 boys) attending to a public secondary school in Manisa province constitute the study group.

In order to carry out all phases of the proposed action research effectively, museums and historic places located in the immediate environment of the school students attending were chosen. Manisa Museum, Muradiye Mosque, Museum of the History of Medicine, Historical Kula Houses, the Ancient City of Sardis, Sultaniye Complex, Keskinoğlu's Museum of Classical Vehicles, Manisa Grand Mosque, and Ravika Village Museum were included in the scope of the research. In total, 34 activities were prepared. Some activities were designed to implement before the museum or historic place visits, some at the museums or historic places and the others were carried out at school after the visits. 21 out of 34 activities were in the form of worksheets, 6 of which required class presentation after conducting out of school research studies in groups and 4 of which were in the form of enactments at museums or historic places. Because learning at museums and historical places appeals to affective domain, three 
activities were performed in creative drama form. The process of qualitative data collection was conducted through observation (the researcher's field notes, the researcher's diaries and the video recordings), focus groups and individual interviews, and written records (the students' diaries, the students' product files, the practiced activities and the parents' opinions forms). The data obtained through observation and interviews was analyzed thematically, while the written records of students' works was subjected to content analysis.

Results: The pre-assessment of students' conceptualization of social studies revealed that they relate social studies to history, geography, law and global connections. However, they started to make connections between social studies and museums, mosques, historical places, graveyards, madrasahs, social complexes, entertainment and museum objects after the implementation of research activities. The categories such as renaissance, civilization and historical personalities in the students' perceptions of social studies leave their places to the categories of historical works of arts, historical empathy and historical objects after the implementation of activities. In respect of grading school subjects, 72 percent of the students put social studies in the $3^{\text {rd, }} 4^{\text {th }}$ or $5^{\text {th }}$ place amongst the all subjects they were taking before the implementation of the research activities. Whereas, all participants started to favor social studies by means of putting it in the first or second place after the implementation of the study. Prior to the study, the participants had indicated that within the content of social studies they enjoy studying topics such as population, communication, inventions and vocations or professions. After the implementation of the study however, they stated that their favored social studies topics were 'A Journey into the Turkish History', 'the History of Manisa', 'Historical Objects and Historical Works'. All these changes in students' perceptions of social studies indicate that the implementation of this action research study had a significant impact on changing the participants' perceptions.

Discussion and Conclusion: The results presented above show that the implementation of research activities in museums and historical places provoked and changed students' perceptions of history. Dönmez and Yeşilbursa's (2014) study reveal that secondary school students perceive of history as a subject mainly comprising of topics related to political history such as wars, peace treaties, agreements and civilizations. These findings accord with the some findings of the current study obtained through the preimplementation stage focus group interviews. However, the analysis of the data collected after the implementation of research activities revealed that the participants' perceptions of history have changed extensively. Their perceptions of history now include and favor local history and cultural elements such as museums and historical places. The number of students who consubstantiate social studies with their real lives has strikingly increased. These results show that the practice of research activities carried out in museums and historical places have changed students' perceptions of social studies in a meaningful way. It is obvious that the enjoyable and meaningful experiences obtained in museums and historic places had impact on the transformation of students' perceptions. Besides, the comparative results of pre and post implementation stage focus group interviews are important for providing an insight on the impact of the activities carried out. These findings also indicate that the practice of 
activities has changed their viewpoints and feelings about the topics or study units located in grade seven social studies curriculum. So, many of them stated in the post implementation phase interviews that they like and wish to learn more about the study unit related to history: 'a Journey in the Turkish History' and topics related to the Ottoman Empire and Turkish culture in the past in addition to the culture of all other Anatolian civilizations. 


\section{Kaynakça}

Açıkalın, M. (2017). Araştırmaya dayalı sosyal bilgiler öğretimi. Ankara: Pegem Akademi.

Adıgüzel, H. Ö., \& Öztürk, F. (1999). Türk eğitim düşüncesinde okul müzesinden müze pedagojisine değişim. Eğitim ve Bilim, 24(114), 73-81.

Akça-Berk, N. (2012). Ortaöğretim 11. Sınıf T.C. Inkılâp Tarihi ve Atatürkçülük dersinde tarihsel canlandırma uygulaması: Bir eylem araştırması (Yayınlanmamış doktora tezi). Gazi Üniversitesi Eğitim Bilimleri Enstitüsü, Ankara.

Aktekin, S. (2008). Müze uzmanlarının okulların eğitim amaçlı müze ziyaretlerine ilişkin görüşleri. Ahi Evran Üniversitesi Kırşehir Eğitim Fakültesi Dergisi,9(2), 103-111.

Aktekin, S. (2009). Lise öğrencilerinin tarih derslerinde yerel tarih konularının öğretilmesiyle ilgili görüşleri. Milli Eğitim, 182, 331-351.

Alazzi, K., \& Chiodo, J. J. (2004). Students' perceptions of social studies: A study of middle school and high school students in Jordan. International Journal of Scholarly Academic Intellectual Diversity, 6(1), 1-12.

Altricther, H., Posch, P., \& Somekh, B. (2000). Teachers investigate their work: An introduction to methods of action research. Routledge: New York.

Ata, B. (2002). Müzelerle ve tarihi mekânlarla tarih öğretimi: Tarih ögretmenlerinin "müze eğitimine” ilişkin görüşleri (Yayınlanmamış doktora tezi). Gazi Üniversitesi Sosyal Bilimler Enstitüsü, Ankara.

Ata, B. (2009). Eğitimde yeni yaklaşımlar. https://sabunagaci.com/2011/10/07/egitimde-yeni-yaklasimlar/ $\quad$ sitesinden

12/08/2017 tarihinde alınmıştır.

Arı, Ç. (2010). Müze bilinci öğrenme alanı etkinliklerinin gerçekleşebilirliğine ilişkin ögretmen görüşleri (Yayınlanmamış yüksek lisans tezi). Anadolu Üniversitesi Eğitim Bilimleri Enstitüsü, Eskişehir.

Avc1-Akçalı, A. (2013). Tarih öğretiminde merkeze băgımlılı̆̆ın azaltılması yolunda bir çözüm önerisi: yerel tarih (Yayınlanmamış doktora tezi). Dokuz Eylül Üniversitesi Eğitim Bilimleri Enstitüsü, İzmir.

Avc1-Akçalı, A. (2015). Kuram ve uygulamada sınıf dışı tarih öğretimi algısı: Öğretmen ve aday öğretmen görüşleri. Ĕgitim ve Bilim, 40(181), 117-137.

Avcı, C., \& Öner, G. (2015). Tarihi mekânlar ile sosyal bilgiler öğretimi sosyal bilgiler öğretmenlerinin görüș ve önerileri. Abant İzzet Baysal Üniversitesi Eğitim Fakültesi Dergisi, 15(USBES Özel Sayısı I), 108-133.

Byford, J. M. (2002). A phenomenological study of middle school and high school students' perceptions of social studies (Unpublished Doctoral dissertation). The University of Oklahoma, Oklahoma. Available from ProOuest Dissertations and Theses database. (UMI No. 3062575). 
Clarke, W. G., \& Lee, J. K. (2004). The promise of digital history in the teaching of local history. The Clearing House: A Journal of Educational Strategies, Issues and Ideas, 78(2), 84-87.

Cohen, L., Manion, L., \& Morrison, K. (2007). Research methods in education (6th ed.). New York: Routledge.

Csikszentmihalyi, M., \& Hermanson, K. (1995). Intrinsic motivation in museums: Why does one want to learn? In J. H. Falk \& L. D. Dierking (Eds.), Public institutions for personal learning (pp. 67-77). Washington, DC: American Association of Museums.

Çengelci, T. (2013). Sosyal bilgiler öğretmenlerinin sınıf dışı öğrenmeye ilişkin görüşleri. Kuram ve Uygulamada Eğitim Bilimleri, 13(3), 1823-1841.

Çerkez, S. (2011). Sosyal bilgiler dersinde müze ĕgitimine dayalı öğretim uygulamalarının öğrencilerin akademik başarısına ve tutumlarına etkisi (Yayınlanmamış yüksek lisans tezi). Kastamonu Üniversitesi Sosyal Bilimler Enstitüsü, Kastamonu.

Çetin, M. (2014). Sosyal bilgiler öğretmen adaylarının eğitiminde müze ortamının kullanılması (Yayınlanmamış yüksek lisans tezi). Akdeniz Üniversitesi Eğitim Bilimleri Enstitüsü, Antalya.

Çulha, B. (2006). Tarihsel mekânlarda keşfederek öğrenme yoluyla sosyal bilgiler ögretimine yönelik ögrrenci görüşleri (Yayınlanmamış yüksek lisans tezi). Dokuz Eylül Üniversitesi Eğitim Bilimleri Enstitüsü, İzmir.

Çulha-Özbaş, B. (2015a). Okul dışı sosyal bilgiler öğretiminde tarihi alanlar. A. Şimşek \& S. Kaymakçı (Eds.), Okul dışı sosyal bilgiler öğretimi (ss. 205-224). Ankara: Pegem Akademi.

Çulha-Özbaş, B. (2015b). Tarih öğretiminde gerçek nesnelerin kullanımı. İ. H. Demircioğlu \& İ. Turan (Eds.), Tarih ögretiminde öğretim teknolojileri ve materyal tasarımı (ss. 117-132). Ankara: Pegem Akademi.

Demir, A. (2015). Sosyal bilgiler öğretim programında müze ĕgitimiyle ilişkilendirilen kazanımların gerçekleştirilmesine yönelik sosyal bilgiler öğretmenlerinin yaklaşımları (Tokat ili örneği) (Yayınlanmamış yüksek lisans tezi). Gaziosmanpaşa Üniversitesi Eğitim Bilimleri Enstitüsü, Tokat.

Demirboğa, E. (2010). Sanal müze ziyaretlerinin öğrencilerin bilişsel ve duyuşsal kazanımları üzerindeki etkileri (Yayınlanmamış yüksek lisans tezi). Gazi Üniversitesi Eğitim Bilimleri Enstitüsü, Ankara.

DeWitt, J., \& Storksdieck, M. (2008). A short review of school field trips: Key findings from the past and implications for the future. Visitor Studies, 11(2), 181-197.

Doğan, Y. (2007). Sosyal bilgiler ögretiminde tarihsel yazllı kanıtların kullanımı (Yayınlanmamış doktora tezi). Gazi Üniversitesi Eğitim Bilimleri Enstitüsü, Ankara. 
Doğan, Y., \& Dinç, E. (2007). Birinci elden tarih kaynaklarının sosyal bilgiler ve tarih derslerinde internet üzerinden kullanımı: ABD ve İngiltere'den uygulama örnekleri. Türkiye Sosyal Araştırmalar Dergisi, 11(2), 195-220.

Dönmez, C., \& Yeşilbursa, C. C. (2014). Ortaokul öğrencilerinin tarih algısı. Gazi Üniversitesi Gazi Eğitim Fakültesi Dergisi, 34(3), 415-436.

Epik, C. (2004). Müzelerin lise öğrencilerinin tarih dersi başarıları ve hatırda tutma becerileri üzerindeki etkileri (Yayımlanmamış yüksek lisans tezi). Dokuz Eylül Üniversitesi Eğitim Bilimleri Enstitüsü, İzmir.

Fernandez, C., Massey, G.C., \& Dornbusch, S. M. (1975). High school students' perceptions of social studies. Stanford, CA: Stanford Center for Research and Development in Teaching. (ERIC Document Reproduction Service No. ED113241).

Filiz, N. (2010). Sosyal bilgiler öğretiminde müze kullanımı (Yayınlanmamış yüksek lisans tezi). Marmara Üniversitesi Eğitim Bilimleri Enstitüsü, İstanbul.

Gartenhaus, A. R. (2000). Yaratıcı düşünme ve müzeler (Çeviri: Ruhiser Mergenci, Bekir Onur). Ankara: Ankara Üniversitesi Basımevi.

Glesne, C. (2014). Nitel araştırmaya giriş (Çev., Ersoy, A. ve Yalçınoğlu, P.) (4. Basım). Ankara: Anı Yayıncılık.

Gökkaya, A. K., \& Yeşilbursa, C. C. (2009). Sosyal bilgiler öğretiminde tarihi yerlerin kullanımının akademik başarıya etkisi. Türk Ĕgitim Bilimleri Dergisi, 7(2), 483506.

Güler, A. (2011). Planlı bir müze gezisinin ilköğretim öğrencilerinin tutumuna etkisi. Illkögretim Online, 10(1), 169-179

Harrison, N. (2012). Putting history in its place: grounding the Australian curriculum history in local community. Paper presented at the Joint Australian Association for Research in Education and Asia-Pacific Educational Research Association Conference (AARE-APERA 2012) (Sydney, New South Wales, Australia, Dec 2$6)$.

Hein, G. E. (1998). Learning in the museum. London: Routledge.

Hensen, K. T. (1996). Teachers as researcher. In. J. Skula (Ed.), Handbook of Research on Teacher Education (Second edition, p: 53-66 ). New York: Macmillan.

Hooper-Greenhill, E. (1999). Müze ve Galeri Eğitimi. (Çev. Meltem Ö. Evren ve Emine G. Kapçı Yay. Haz. Bekir ONUR). Ankara: Ankara Üniversitesi Çocuk Kültürü Araştırma ve Uygulama Merkezi Yayınları. (Orijinal eserin yayın tarihi 1991).

Hooper-Greenhill, E. (2007). Museums and education: Purpose, pedagogy, performance. Routledge.

Horton, J. O. (2000). On-site learning the power of historic places. Cultural Resource Management, 23(8), 4-6.

Husbands, C. (1992). Objects, evidence and learning: some thoughts on meaning and interpretation in museum education. Journal of Education in Museums, 13, 24-28. 
International Council of Museums. (ICOM). (2007). Museum Definition. Retrieved on 02/04/2017 from http://icom.museum/the-vision/museum-definition/

Işık, H. (2008). İlköğretimde tarih konularının yerel tarih ile ilişkilendirilmesinin öğrenci başarısına etkisi. Uluslararası Sosyal Araştırmalar Dergisi, 1(4), 290-310.

Kabapınar, Y. (2014). Kuramdan uygulamaya sosyal bilgiler ögrretimi. Dördüncü Bask1. Ankara: Pegem akademi.

Kısa, Y. (2012). Sosyal bilgiler öğretiminde müze kullanımına ilişkin öğretmen ve ögrenci görüşlerinin incelenmesi: Afyonkarahisar müzeleri (Yayınlanmamış yüksek lisans tezi). Afyon Kocatepe Üniversitesi, Afyonkarahisar.

Meredith, J. E.,Fortner, R. W., \& Mullins, G. W. (1997). Model of affective learning for nonformal science education facilities. Journal of Research in Science Teaching, $34,805-818$.

Miles, M. B. \& Huberman, A. M. (1994). Qualitative data analysis: An expanded source book. London: Sage.

Mitchell, K. \& Elwood, S. (2012). Engaging students through mapping local history. Journal of Geography, 111(4), 148-157.

Nişancı, M. G. (2010). Tarihsel çevrenin tarih ĕgitimine etkisi: Adalar örneklemi (Yayınlanmamış yüksek lisans tezi). Marmara Üniversitesi Eğitim Bilimleri Enstitüsü, İstanbul.

Öner, G. (2015). Sosyal bilgiler öğretmenlerinin okul dışı tarih öğretimine ilişkin görüşlerinin incelenmesi. Türk Tarih Ĕ̆itimi Dergisi, 4(1), 89-121.

Özkal, N., Güngör, A., \& Çetingöz, D. (2004). Sosyal bilgiler dersine ilişkin öğretmen görüşleri ve öğrencilerin bu derse yönelik tutumları. Kuram ve Uygulamada Ĕ̆itim Yönetimi, 10(4), 600-615.

Punch, K. F. (2005). Sosyal araştırmalara giriş (Çev. D. Bayrak, H. B. Arslan, ve Z. Akyüz). Ankara: Siyasal Kitabevi.

Rix, C. \& McSorley, J. (1999). An investigation into the role that school-based interactive science centres may play in the education of primary-aged children. International Journal of Science Education, 21, 577-593.

Seidel, S. \& Hudson, K. (1999). Müze eğitimi ve kültürel kimlik (Çev: Bahri Ata). Ankara: Ankara Üniversitesi Sosyal Bilimler Enstitüsü Müze Eğitimi Anabilim Dalı Yayınları No:1

Şar, E. \& Sağkol, T. (2013). Eğitim fakültelerinde müze eğitimi dersi gerekliliği üzerine. Hasan Ali Yücel Ë̆itim Fakültesi Dergisi, 10(2), 83-90.

Şimşek, A. \& Kaymakçı, S. (2015). Okul Dışı Sosyal Bilgiler Öğretiminin Amacı ve Kapsamı. In A. Şimşek \& S. Kaymakçı, (Eds.), Okul dışı sosyal bilgiler öğretimi. (ss. 1-13). Ankara: Pegem Akademi.

Tezcan-Akmehmet, K. (2005). Ilköğretim sosyal bilgiler öğretiminde arkeoloji müzelerinin nesne merkezli ĕgitim etkinlikleriyle kullanılması (Yayınlanmamış Doktora Tezi). İstanbul Teknik Üniversitesi Sosyal Bilimler Enstitüsü, İstanbul. 
Tezcan-Akmehmet, K. (2008). Müzelerin tarih öğretiminde nesne merkezli eğitim etkinlikleriyle kullanılması ve ilköğretim sosyal bilgiler öğretimi. Milli Eğitim Dergisi, 180(4), 50-67.

Tokcan, H. (2015). Okul dışı sosyal bilgiler öğretimi ve öğrenme teorileri. In A. Şimşek \& S. Kaymakçı (Eds.), Okul dışı sosyal bilgiler öğretimi (ss. 15-42). Ankara: Pegem Akademi.

Tuffy, J. (2011). The learning trip: using the museum field trip experience as a teaching resource to enhance curriculum and student engagement (Unpublished master dissertation). Dominican University of California, United States.

Tunç-Şahin, C. (2011). Yerel tarih uygulamalarının başarıya ve öğrenci ürünlerine etkisi. Uluslararası Sosyal Araştırma Dergisi, 16, 453-462.

Wellington, J. (1990). Formal and informal learning in science: The role of the interactive science centres. Physics Education, 25, 247-252.

Yeşilbursa, C. C. (2008). Sosyal bilgiler öğretiminde tarihi yerlerin kullanımı. TÜBARXXIII http://dergipark.gov.tr/download/article-file/156925 sitesinden 12/08/2017 tarihinde alınmıştır.

Y1lmaz, K. \& Şeker, M. (2011). İlköğretim öğrencilerinin müze gezilerine ve müzelerin sosyal bilgiler öğretiminde kullanılmasına ilişkin görüşlerinin incelenmesi. Ístanbul Aydın Üniversitesi Fen Bilimleri Dergisi, 1(3), 21-39.

Yorulmaz, E. (2016). Sosyal bilgiler dersi kapsamında okul dışı çevrelerin kullanımı: Çorum yatılı arkeoloji müzesinde bir gün. (Yayınlanmamış yüksek lisans tezi). Cumhuriyet Üniversitesi Eğitim Bilimleri Enstitüsü, Sivas.

Zayimoğlu-Öztürk, F. (2014). Sosyal bilgiler dersinde arkeolojik kazı çalışması ve müze gezisi. Araştırma Temelli Etkinlik Dergisi, 4(1), 12-26. 